\title{
Asian Crop Dispersal in Africa and Late Holocene Human Adaptation to Tropical Environments
}

\author{
Robert C. Power ${ }^{1,2,3,4}$ [ $\cdot$ Tom Güldemann ${ }^{5,6} \cdot$ Alison Crowther $^{1,7}$ (1) \\ Nicole Boivin ${ }^{1}$
}

Published online: 21 November 2019

(C) The Author(s) 2019

\begin{abstract}
Occupation of the humid tropics by Late Holocene food producers depended on the use of vegetative agricultural systems. A small number of vegetative crops from the Americas and Asia have come to dominate tropical agriculture globally in these warm and humid environments, due to their ability to provide reliable food output with low labour inputs, as well as their suitability to these environments. The prehistoric arrival in Africa of Southeast Asian crops, in particular banana, taro and greater yam but also sugar cane and others, is commonly regarded as one of the most important examples of transcontinental exchanges in the tropics. Although chronologies of food-producer expansions in Central Africa are increasingly gaining resolution, we have very little evidence for the agricultural systems used in this region. Researchers have recovered just a handful of examples of archaeobotanical banana, taro and sugar cane remains, and so far none from greater yam. Many of the suggested dispersal routes have not been tested with chronological, ecological and linguistic evidence of food producers. While the impact of Bantu-speaking people has been emphasised, the role of non-Bantu farmers speaking Ubangi and Central Sudanic languages who have expanded from the (north)east has hardly been considered. This article will review the current hypotheses on dispersal routes and suggest that transmissions via Northeast Africa should become a new focus of research on the origins of Asian vegeculture crops in Africa.
\end{abstract}

Keywords African history · Archaeobotany $\cdot$ Agriculture $\cdot$ Rainforest colonisation · Bantu expansion

Electronic supplementary material The online version of this article (https://doi.org/10.1007/s1096 3-019-09136-x) contains supplementary material, which is available to authorized users.

Robert C. Power

r.power@1mu.de

Extended author information available on the last page of the article 


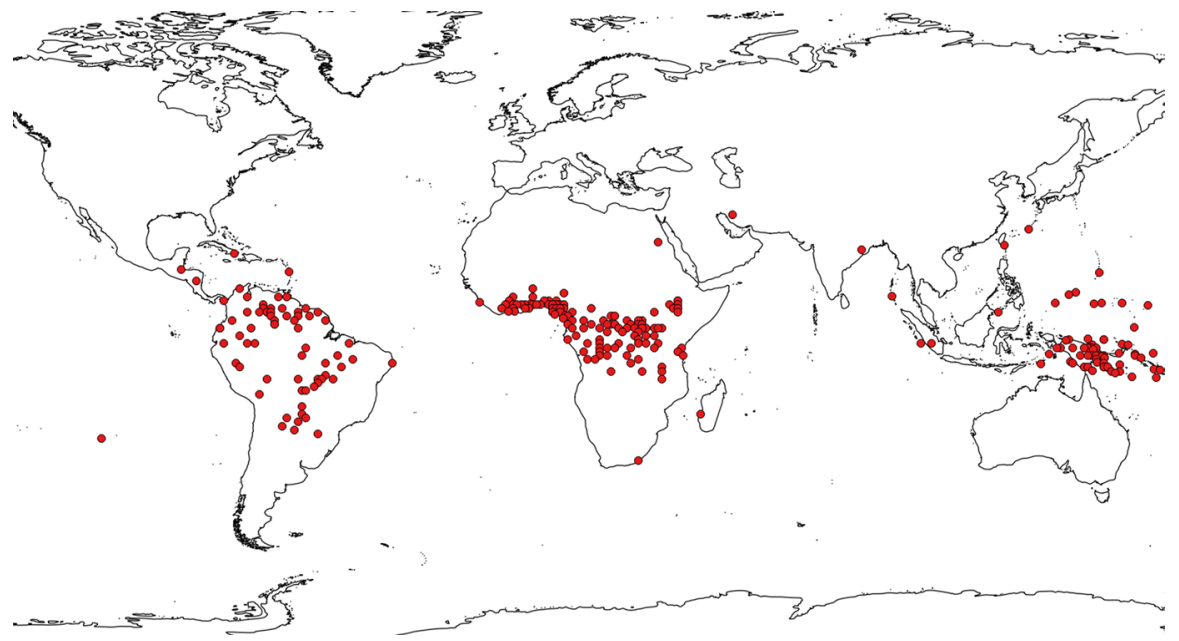

Fig. 1 The distribution of the traditional taro, yam, banana and fruit-based societies. As tuber, corm and fruit crop complexes are a distinct mid-latitude adaptation, the history of these crops is crucial for understanding the formation of human societies in these regions. Data from D-PLACE (Gray 1999; Kirby et al. 2016; Murdock 1967)

\section{Introduction}

In humid tropical regions of the world the nutrition of hundreds of millions of people today depends on the cultivation of tubers, corm and fruit crops such as manioc (Manihot esculenta), bananas (Musa spp.), yams (Dioscorea spp.) and taro (Colocasia esculenta). Nearly all major tuber, corm and fruit crops originated from wild progenitors in Southeast Asia, Near Oceania (particularly Papua) and South America, but today they are truly global staples, grown in the hot and humid regions of nearly every continent. These plants are favoured for many reasons, not least because they provide a reliable source of energy, even on the most leached tropical soils, where grain staples are difficult or just impractical to grow. It is generally presumed that the centres of domestication of these tuber, corm and fruit complexes arose later than those of grain-based agriculture but it is clear their impact on world history was no less important (Iriarte 2007). Once established, tuber, corm and fruit complexes allowed productive agriculture, and thus fostered new ways of life and population growth in these areas (Fig. 1). These have not only shaped tropical economic systems but have also had profound evolutionary influences, shaping human genomes in areas where they grow, with repercussions to this day (Albuquerque et al. 2015).

The development of African farming presents a unique case study highlighting the importance of food crop globalisation, especially of tropical tubers, corms and fruits. Strategies of mobile livestock herding developed in Africa some time from the 8th to the 6th millennium BC, apparently independent of plant cultivation for thousands of years (Marshall and Hildebrand 2002; Winchell et al. 2017). While herding spread throughout arid and grassland ecosystems, it was not viable in the humid tropics due to the prevalence of livestock diseases (Gifford-Gonzalez 2000, 
2017). Africa's equatorial rainforest has been termed a 'viral forest' in light of its concentrations of transmissible diseases that plague settlement (Zerner 2003). It was not until the arrival of domesticated plants that food production could take hold in these environments even though foragers colonised them effectively from at least the Pleistocene (Cornelissen 2002).

Current evidence based on charred plant remains, pottery and pollen suggests that agricultural societies only emerged in humid regions of Africa around 1500-500 BC (Neumann et al. 2012), some two millennia after agriculture first appeared in the Sahel zone of West Africa (Manning et al. 2011), and possibly seven millennia after it appeared in the northeastern Sahara (Gautier 1984; Honegger 2005). The first archaeologically attested crops raised in the Central and West African tropics were the arid-adapted crops pearl millet (Pennisetum glaucum) and cowpea (Vigna unguiculata), and the humid forest crop oil palm (Elaeis guineensis) (D'Andrea et al. 2007). These have a contrasting history to tropical Asian crops, and are commonly thought to have been spread throughout the rest of sub-Saharan Africa by Bantuspeaking people dispersing from present day Cameroun (Murdock 1959; Neumann et al. 2012; Vansina 1990).

Researchers know very little about how farming was adapted to the humid Central African forests, even though this is crucial for understanding the peopling of the equatorial forest region. It is also important for the settlement of the drier zones that exist to the south. The rainforest zone forms a substantial barrier from the Atlantic Coast in the west to the East African Plateau near Lake Victoria, being too damp to be ideal for the pearl millet and cowpea agriculture that was developed in the Sahel. Food producing populations, who arguably also spread the Bantu languages, must have either crossed or circumnavigated the Central African forests during their expansion into southern Africa, potentially developing new vegeculture packages during this time (Grollemund et al. 2015; Kahlheber et al. 2014a; Neumann et al. 2012; Ngomanda et al. 2009).

Researchers have looked to crops that are cultivated in Central Africa today and investigated whether they may have been adopted early enough to be a significant part of the Bantu expansion. Of the crop packages that are popular at present, we know that crops originating in the New World only appeared following interactions with European trade in the 1500s, but several major crops that originated in Southeast Asia (bananas, greater yam, taro and sugarcane) arrived in Africa in prehistory. Table 1 lists these four Asian crops together with similar ones from Africa itself and the Americas, which are all relevant for the historical understanding of such new agricultural package(s). We also include wild African forms in order to point to their local pre-agricultural use and subsequent domestication.

In some cases African oral history recounts the American introductions (Thomas 1940), but oral history does not explain when bananas, greater yam, taro and sugarcane arrived in Africa. A number of other tropical Asian crops have a traditional role in Africa including mango (Mangifera indica), jackfruit (Artocarpus heterophyllus), Asian breadfruit (Artocarpus altilis), and rambutan (Nephelium lappaceum) (Morton 1987; Murdock 1959; Szolnoki 1985). Some of these probably represent recent colonial arrivals but others may have arrived earlier, potentially within the last thousand years, via Indian Ocean trade, but had limited distribution along the West 
Table 1 Southeast Asian crops and similar domesticated and wild plants from Africa and the New World

\begin{tabular}{|c|c|c|c|}
\hline Asian crops & Similar African crops & $\begin{array}{l}\text { Similar African wild } \\
\text { species }\end{array}$ & Similar American crops \\
\hline $\begin{array}{c}\text { Banana/plantain (Musa } \\
\text { balbisiana, Musa } \\
\text { acuminata, hybrids) }\end{array}$ & $\begin{array}{l}\text { Enset/false banana } \\
\quad(\text { Ensete ventricosum })\end{array}$ & $\begin{array}{l}\text { Enset } \\
\text { (Ensete ventricosum) }\end{array}$ & \\
\hline $\begin{array}{l}\text { Taro/old cocoyam } \\
\text { (Colocasia esculenta) }\end{array}$ & & & $\begin{array}{l}\text { New cocoyam } \\
\text { (Xanthosoma spp.) }\end{array}$ \\
\hline $\begin{array}{l}\text { Asian aerial yam } \\
\text { (Dioscorea bulbifera), } \\
\text { Greater/water yam } \\
\text { (D. alata), } \\
\text { Lesser yam } \\
\text { (D. esculenta) }\end{array}$ & $\begin{array}{l}\text { African aerial yam } \\
\text { (Dioscorea bulbifera), } \\
\text { White Guinea yam } \\
\text { (D. rotundata), } \\
\text { Yellow Guinea yam } \\
\text { (D. cayenensis), } \\
\text { Cluster/bitter yam } \\
\text { (D. dumetorum) }\end{array}$ & $\begin{array}{l}\text { Wild yam } \\
\text { (Dioscorea spp.) }\end{array}$ & $\begin{array}{l}\text { Manioc/cassava } \\
\text { (Manihot esculenta) }\end{array}$ \\
\hline $\begin{array}{l}\text { Sugar cane } \\
\text { (Saccharum officinarum) }\end{array}$ & & & - \\
\hline
\end{tabular}

Table 2 Potential dispersal routes of Asian crops in Africa

\begin{tabular}{llll}
\hline Route & Transfer to Africa & Entrance in Africa & Diffusion in Africa \\
\hline A & Atlantic Ocean & West Central Africa & Eastward \\
B & Indian Ocean & East Africa & Westward \\
C & West Asia & Northeast Africa-Egypt & Southward \\
D & Circum-Indic & Horn of Africa-Ethiopia & Southwestward \\
\hline
\end{tabular}

and East African coasts until the last 200 years (Morton 1987; de Schlippe 1956). Although widely grown today, none of these crops are economic staples because fruit trees such as the mango are poorly suited to shifting cultivation systems, which predominate in the humid forest (de Schlippe 1956).

Different linguists and archaeologists have argued that a multitude of agents were involved in the transportation of Asian crops to Africa (Table 2), including Austronesians (via Madagascar or by an East African mainland coast route)—either before the first millennium BC (Blakney 1963; De Langhe and De Maret 1999; Ehret 2016; Lejju et al. 2006) or later in the first millennium AD (Rossel 1998; Simmonds 1962); Cushitic-speaking NE Africans (Murdock 1959); Arab traders around the 8th century AD (Wigboldus 1994); and others (De Langhe and De Maret 1999; Lejju et al. 2006; Murdock 1959; Price 1995; Simmonds 1962; Watson 1983; Wigboldus 1994). The timing of the appearance of these crops in Africa is of crucial importance for reconstructing the development of farming societies in the humid African tropics, where they are now the bedrock of farming (Castillo and Fuller 2015; Fuller et al. 2011; Mbida Mindzié et al. 2000; Murdock 1959, 1960; Simmonds 1962; Vansina 1990; Watson 1983). In this paper, we explore the history of these crops by 
reviewing evidence of Asian crops in Africa with the latest insights from archaeology, crop ecology and linguistics, and examine their relevance to the spread of farming in the African tropics.

\section{Geography, Ecology and Plant Biology}

Asian tropical crops are an important part of the agricultural adaptations to humid climates of Central Africa. Despite this, each of these crops emerged from wild progenitors that are native to distinct habitats in tropical rainforest and monsoon climates stretching from peninsular Southeast Asia to New Guinea.

\section{Banana}

Banana is a tree-like perennial herb of the genus Musa, one of two genera in the monocotyledonous family Musaceae, alongside Ensete. Musa only naturally occurs in a band from eastern India to Papua, where it grows in clearings in rainforest environments. Domestic banana derives from multiple intra- and inter-specific hybridization of Musa acuminata (A genome) native to Southeast Asia from Myanmar to Papua, and Musa balbisiana (B genome), whose wild range is believed to stretch approximately from India to South China (Fig. 2) (D'Hont et al. 2012; Perrier et al. 2011; Simmonds 1962).

Bananas are extremely widespread across Africa today and grow in many regions that may have been prehistoric dispersal routes, some of which have been overlooked in past studies of banana distribution (Murdock 1959). Banana distribution depends on variety, and while there are many cultivars world-wide, only two cultivar groups are of primary importance in Africa. The first is the AAB group, a starchy triploid banana whose centre of diversity occurs in Central Africa. Although as a whole, like all African bananas, their diversity is low (Kitavi et al. 2016), this group has the highest number of cultivars and is thus thought to have been in Africa the longest. The second group is the East African Highland AAA, a starchy banana also with a high number of cultivars that is dominant c. $1200 \mathrm{~m}$ above sea level in the interlacustrine region around Lake Victoria (Rossel 1998). In contrast, sweet dessert banana, found mainly in the East African coast region, are low diversity diploid or triploid cultivars derived solely from $M$. acuminata (AA and AAA); some sweet bananas are tetraploid hybrids (AAAA). These bananas have low cultivar numbers and are probably colonial-era introductions (Rossel 1998).

Banana is a reliable and seasonless cropper, provided sufficient moisture and light are available, with only limited labour requirements. Climatic requirements do vary according to hybrid type. Unlike their wild progenitors, domestic banana is totally dependent on humans for dispersal due to its sterility. Banana groves will last for approximately thirty years but, if abandoned in their typical forested setting, they will rapidly perish due to forest canopy growth (Hanna 1964; Reed 2015). The process of domestication involved selection for parthenocarpy and seed sterility, transforming wild banana from bitter seedy fruits into fleshy seedless parcels of sugar and starch. Wild 


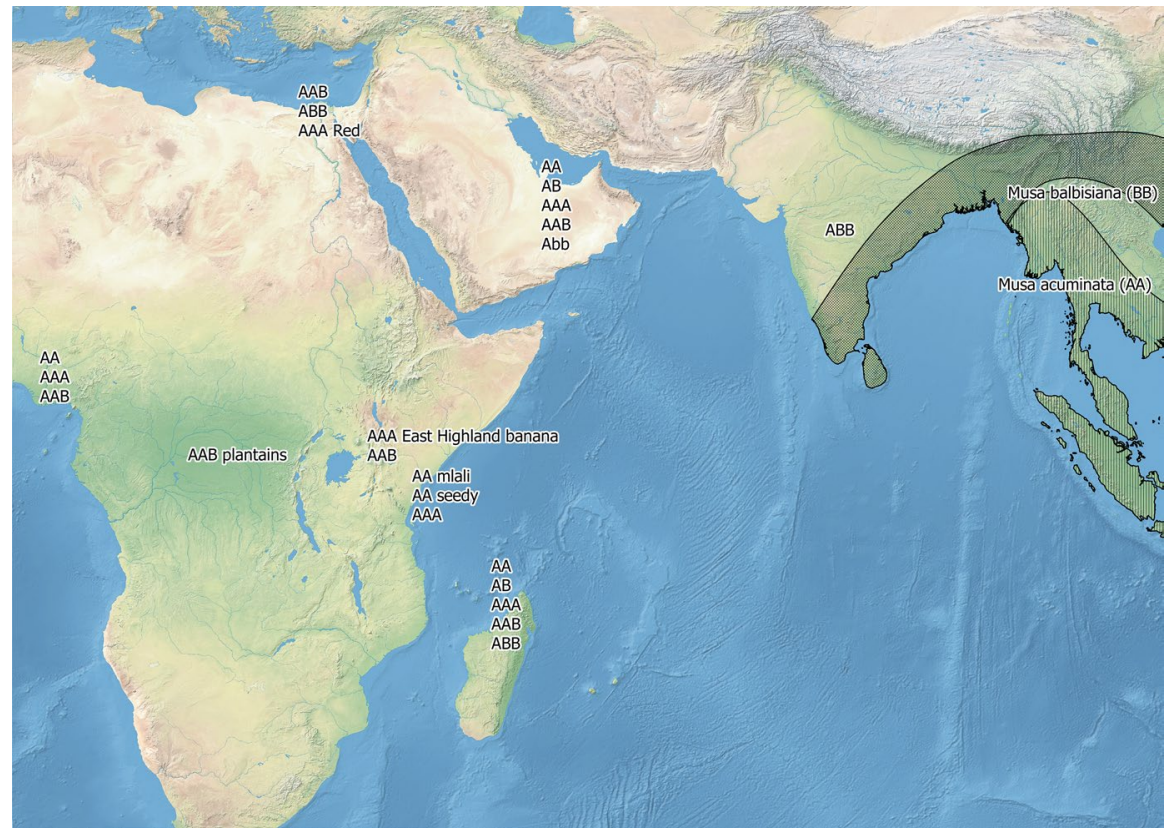

Fig. 2 A map of the estimated wild range of Musa acuminata (A genome) and M. balbisiana (B genome) and genetics of African banana cultivars

bananas are not only ill-tasting and seedy but they are a poor food, as sugars cause the fruit's large seeds to bind together, leading to alimentary tract obstruction if consumed, but records of consumption do exist and some societies may grind seeds into flour or collect them for beads (Johnston 1904a; Rossel 1998; Schöffl et al. 2004; Slesak et al. 2011). The unpalatability of wild bananas suggests that if they were important in their centre of domestication or elsewhere, it was originally as a source of fibre for cordage, leaves for shelters and basketry, or seed use (Fuller and Madella 2009; Kennedy 2009).

The less studied Musaceae genus enset (Ensete) may be important in understanding banana dispersals; its deep history in Africa has been commonly seen as fostering a cultural readiness for banana cultivation (De Langhe 2007; De Langhe et al. 1995). Enset which produces inedible fruit, is native to Asia and Africa (Simmonds 1962). It occurs in upland areas throughout the humid African tropics but is generally rare outside Southwest Ethiopia where it was domesticated for its starchy pseudostem and corm at an unknown date and today is a regional staple (Hildebrand 2007). Domesticated enset produces seed but is propagated vegetatively (Hildebrand 2007).

\section{Taro}

Taro (C. esculenta), also known as cocoyam, is a perennial corm that belongs to the monocotyledonous family Araceae. Although not related to yams (family Dioscoreaceae), in some regions such as South Asia taro and other aroids are locally known 
as yams (Panghal and Rana 2017). The Colocasia genus and wild forms of taro are thought to be native to South and peninsular Southeast Asia and island Southeast Asia and New Guinea. Although once thought to be a number of species, taro is now commonly understood to be a highly variable species with diploid and triploid forms (Plucknett 1976). Taro's edible, starch-rich corm is an important food in much of East Asia, the Pacific, Madagascar and West Africa, and it has smaller outposts in East, South, North and Central Africa including the Swahili Coast, the interlacustrine area, southern Sudan, the Nile Valley and the Eastern Cape (Amadiume 2003; Fujimoto 2009; Grimaldi 2016; Vilakazi 1962). Its distribution in African traditional agricultural systems is thus wider than in Murdock's reconstruction (1959); its importance in Africa as a food is, however, much less than that of banana. Like banana, taro leaves are used as a food wrapping. Even when not being cultivated, taro is often found growing feral by human settlements, presumably as a relic of past cultivation, unlike domesticated banana, which is fully dependent on humans. Cultivated and wild/feral taro is not necessarily clearly defined; wild/feral populations may be used as a food source (Ivancic and Lebot 2000). Taro requires high levels of labour input in order to achieve high yields. It has similar growing requirements to banana, but unlike banana and yam, taro tolerates waterlogging and moderate shade (Onwueme 1999).

\section{Greater Yam}

True yams are perennial herbaceous monocotyledonous vines that produce starchy tubers. They are members of the cosmopolitan Dioscoreaceae family, which are native to six continents and are an indigenous domesticate on at least five. In Africa, at least two of the domesticated members are Southeast Asian in origin, greater yam, also known as water yam (Dioscorea alata), and lesser yam (Dioscorea esculenta), while some contend that Asian aerial yam (Dioscorea bulbifera) is also of Asian origin (Burkill 1939, 1960; Hammer 1998). There are two domesticated indigenous African yams, Guinea yam (Dioscorea cayenensis) and a subspecies of white yam (Dioscorea cayennensis subsp. rotundata). Guinea and white yam are adapted to drier conditions than Asian yams (Inglett and Charalambous 1979) and are mostly associated with West Africa, the northernmost part of the Congo Basin, Uganda, Southwest Ethiopia and Madagascar, and appear to be very rare or absent in the Inner Congo Basin (Burkill 1939; Hildebrand 2003, 2009). In addition there are dozens of wild Dioscorea species which are collected by farmers and foragers alike as a staple or famine food (Ichikawa and Terashima 1996; Terashima 2003; Walsh 2009; Williamson 1975). Dioscorea tubers contain toxins such as saponin, which are removed by cooking (Johns and Kubo 1988). Phenotypically, most of these wild species are extremely similar to domesticated yams and they require advanced botanical knowledge to distinguish.

Of the Asian crops, greater yam is much more dominant in Africa than lesser yam and is grown intensively in a belt of West Africa pockets but is also used less intensively across Central Africa, East Africa and Madagascar. Yams are typically infrequent or rare in the interlacustrine region of East Africa where banana is more 
important (Johnston 1904b). The intensive cultivation yam belt does not extend into the Central African humid zone as Murdock described (Murdock 1959). Overall the economic importance of yams in Africa is like that of taro and much less than banana. In much of their range, it is common to find examples of domesticated species that have gone wild and have lost their ennobled traits and produce highly bitter tubers. Seed tubers of greater yam, like taro, normally have a long dormancy period of up to half a year or more (Craufurd et al. 2001). Some types of lesser yam have short dormancy periods, perhaps explaining why greater yam and taro are commonly transoceanic crops, unlike lesser yam. All yams require highly fertile soils, uninterrupted wet seasons and high labour input relative to other tropical crops, which may limit their value in thinly-populated Central Africa which is dominated by infertile soils (Diby et al. 2009).

\section{Sugarcane}

Sugarcane is a common term for several closely related perennial tropical grass species (family Poaceae) whose tough pith is rich in the sugar sucrose. Most of the progenitors are native to Southeast Asia but the range of some species reaches into Africa. Sugarcane history bears many similarities to bananas, taro and yams (Denham 2011) but it is not a starchy staple so its role in African history is neglected, despite it being a local staple and geographically more widespread today in traditional African subsistence than banana, yams and taro combined (Denham 2011). Other grass crops, such as sorghum and maize are sometimes also used for the sugar in their stalks similarly to sugarcane (Williamson 1975). Sugarcane is extensively used all over sub-Saharan Africa where warm moist conditions are available. Sugarcane has similar growing requirements to banana, taro and yams but with comparatively greater flexibility (Simmonds 1976).

\section{Archaeology and History}

\section{Banana}

The domestication of banana is believed to have occurred through conscious or wild hybridisation events, some of which occurred after human-mediated or natural changes in the range of the two wild banana species (M. acuminata and M. balbisiana), with fruits developing parthenocarpy and consequently seedlessness (D'Hont et al. 2012; Perrier et al. 2011). How complicated this was is unclear, but if the process of developing parthenocarpy and consequently sterility occurred quickly further introgression from wild populations would not have been possible. This process may have included Papua, the Solomon Islands and the Philippines and occurred several thousand years ago (D'Hont et al. 2012; De Langhe and De Maret 1999). However, the complex genetic pasts of the many different cultivars have so far confounded attempts to trace when they spread outside their natural range to Africa, where they became hugely important in the humid zones. 
Banana produces characteristic starches and diagnostic phytoliths and seeds, but only phytoliths have played a significant role in the debate on early banana in Africa (Lejju et al. 2005, 2006; Lentfer 2009; Mbida Mindzié et al. 2000). Banana produces diagnostic volcaniform phytoliths with characteristic protuberances in its leaves and rugulose types in its seeds. Although its sister genus, Enset, is native to Africa and also produces volcaniform phytoliths, they are morphologically distinct in that they lack protuberances amongst other features (Mbida Mindzié et al. 2001), while its distinct seeds are irregularly globose, lenticular (Cheesman 1947).

The earliest direct archaeological evidence of the use of banana comes from phytoliths at the Batadomba-lena rock shelter in Sri Lanka, in a layer dated to 36,300-34,600 cal BP (Perera et al. 2011). At the site of Kitulgala Beli-Lena, also in Sri Lanka, banana seeds of both wild Musa cf. acuminata and M. balbisiana were found in terminal Pleistocene/early Holocene deposits (Kajale 1989), leading De Langhe (2009) to suggest that foragers had begun to alter banana biogeography by at least this time period. However, given the proximity of the site to the consensus natural range of wild banana, the possibility of non-human dispersal, such as by frugivorous bats, should also be seriously considered (Boon and Corlett 1989). MidHolocene banana domestication at the Kuk Swamp site in New Guinea has been proposed based on banana phytoliths, and suggested taro and yam starches alongside the archaeological remains of cultivation plots and palaeoecological evidence for landscape clearance of local montane forest into grasslands (Denham et al. 2003, 2004; Fullagar et al. 2006; Lentfer and Denham 2017). While the combined multiproxy evidence is strongly indicative of cultivation, most likely leading to domestication, it is notable that these microbotanical identifications do not reveal directly if these plants were wild, cultivated (managed to increase food yield) or domesticated (human genetic modification to increase food yield). Rather, high confidence estimates for banana domestication depend on the appearance of archaeobotanical remains or historical evidence outside its native range. Currently the earliest credible example of such evidence derives from sediment phytoliths, ten banana phytoliths were found dated to 2500-1900 BC at Kot Diji, Sindh in NW India (Madella 2003).

In Africa, banana phytoliths have been reported at two early (pre-AD 1000) sites: Munsa in Uganda dating from 3220 cal BC to cal AD 1110 (Lejju et al. 2005), and Nkang in Cameroon dating to 700-315 cal BC (Mbida et al. 2005; Mbida Mindzié et al. 2000, 2001). The identification of the Munsa phytoliths as banana has been considered unreliable, with the possibility that the remains are not even phytoliths also being raised (Neumann and Hildebrand 2009). Early doubts on the identification of the Nkang phytoliths as Musa were voiced on the grounds of potential morphological overlap with phytoliths from native Ensete (Vansina 2003), however the identification of the Nkang phytoliths as banana is now considered robust (Neumann and Hildebrand 2009; Perrier et al. 2011). Although the Nkang phytoliths are accepted as Musa, the early date for banana at Nkang is not accepted by all, due to the low numbers of phytoliths $(n=25)$ (Perrier et al. 2011), the lack of banana phytoliths in more recent sediments and the possibility of stratigraphic mixing (Neumann and Hildebrand 2009; Vansina 2003). Banana aDNA has been reported from 500-1300 AD figures from Ghana; however the current difficulties in using plant 


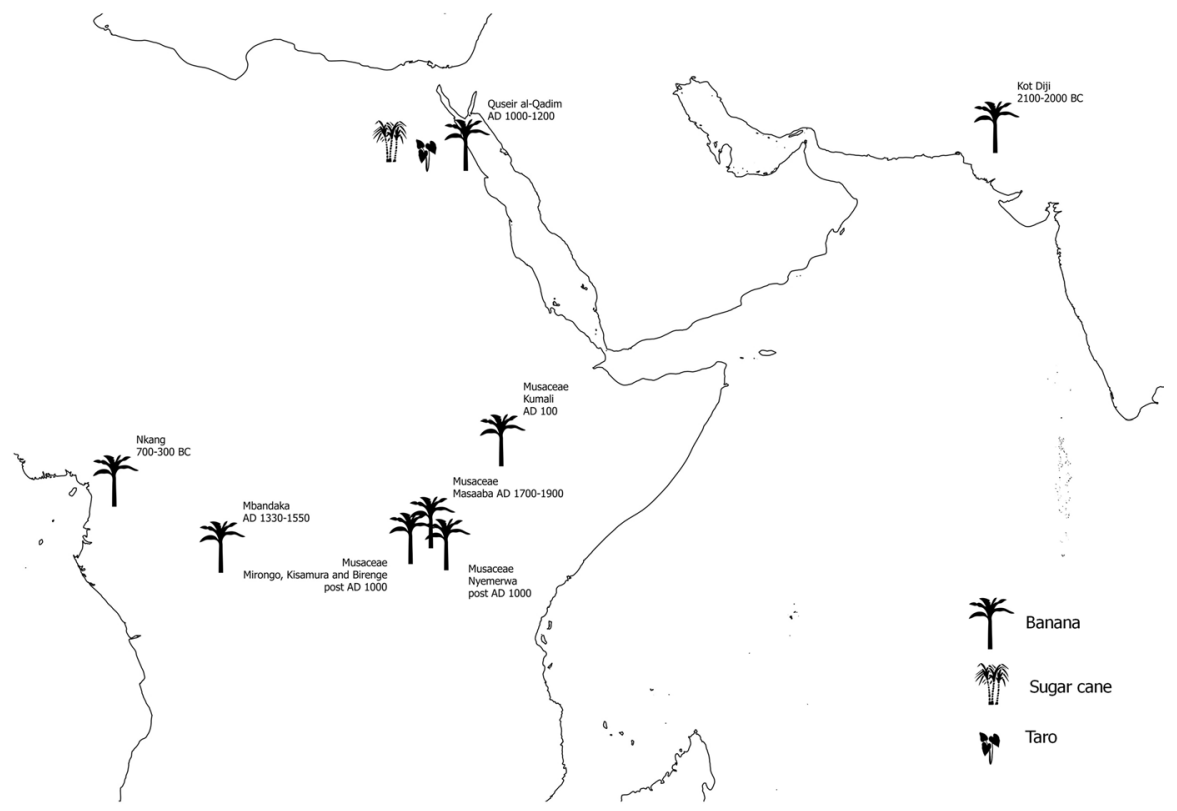

Fig. 3 The extent of archaeobotanical finds of banana, taro, yams and sugarcane as well as an unidentified Musaceae leaf that represents either banana or enset

aDNA warrant caution in interpreting this evidence (Robinson et al. 2017). Examples of early accepted evidence are limited to Mbandaka in the Inner Congo Basin, dating to cal AD 1330-1550 (See Fig. 3; Eichhorn and Neumann 2015). It should be noted that recovery of phytoliths in archaeological sites can be challenging, with some plants that produce low numbers. It is unclear if bananas are rich phytolith producers, but available evidence from the Japanese fibre banana (Musa basjoo Siebold \& Zucc. ex Iinuma) suggests bananas are not a low phytolith producer and perhaps should not be rare on archaeological sites; however, it is possible that banana phytoliths are particularly susceptible to breakdown and that this accounts for their rarity (Hodson et al. 2005).

The earliest historical reference to banana in Africa is the mention by Cosmas of an Ethiopian fruit called 'moza' around AD 525. While some consider this to refer to banana, it is ambiguous (Rossel 1998). The earliest reliable historical evidence of banana comes from the Arab world and the writer Al-Masudi, who refers to banana on the East African coast from AD 915 (Rossel 1998). It is clear that banana was also grown in Egypt, Yemen and Iraq at this time, but Arab texts provide no clues to their cultivar groups (Rossel 1998). Banana rind has been found along with the remains of taro, coconut and sugarcane in Islamic deposits dating to AD 1000-1200 at the trading hub at Quseir al-Qadim, Egypt (van der Veen and Morales 2011, 2017). Their absence from the earlier and archaeobotanically rich late Roman-period levels suggests, however, that a pre-Islamic introduction is unlikely. It is unclear what cultivar the Quseir al-Qadim find is, but future aDNA extraction could provide some insights. 


\section{Taro}

The early history of taro is poorly understood, but the characteristics of wild forms suggest that taro was domesticated to reduce corm toxicity in several locations in the wetlands of peninsular Northeast India, Southeast Asia or Papua. Phytogeographic and genetic evidence indicates this occurred several thousand years ago in Papua (Chaïr et al. 2016; Inglett and Charalambous 1979; Ivancic and Lebot 2000; Kreike et al. 2004; Lebot 1999; Matthews 1995). Taro cultivation has been reported at Kuk Swamp, based on documentation of starches potentially relating to taro, alongside evidence of landscape clearance and anthropogenic drainage features (Denham et al. 2003, 2004; Fullagar et al. 2006). Historical records show that domesticated taro dispersed into China by 2200 years ago (Huang 2012). In the Near East, early historical descriptions of a crop that was termed Colocasia are available, leading some to suggest taro had reached Egypt from India by 300 BC and Italy by AD 200, known as Cyrenaic aron in Galen (Burkill 1938; Grimaldi et al. 2018; Sallares 1991). Yet, in cases where this crop of antiquity has descriptions, they appear to refer to lotus rather than taro until the 2nd century AD (Grimaldi 2013; Watson 1983). The only known archaeobotanical specimen of taro, desiccated corm fragments that have been recovered at Quseir al-Qadim on the Red Sea Coast in Egypt, show taro was probably established in Northeast Africa by at least AD 1050-1170. Accompanying historical records suggest the crop was already a local food and not traded through the port (van der Veen 2011). Other historical evidence verifies taro was widely grown along the Nile by AD 1000 (Grimaldi 2016; Grimaldi et al. 2018; van der Veen and Morales 2017). It is far less certain when taro dispersed into sub-Saharan Africa, but genetic surveys of diversity suggest multiple introductions (Chaïr et al. 2016). Historical evidence from the Arab traveller Ibn Battuta and others also appears to suggest that taro was too well established in West Africa in the 1300s to have been spread by the Portuguese (Grimaldi 2016; Watson 1983).

\section{Greater Yam}

In trying to establish the history of greater yam, we encounter the same problems as with banana, but compounded by both the enormous diversity in the yam family, Dioscoreaceae, and the indigenous domestication of the closely-related Guinea yam in Africa. Just as with banana and taro, domestication of greater yam at around 5000-4400 BC has been proposed based on starch finds at Kuk Swamp (Denham et al. 2003), but currently domestication can only be traced with genetics (Ngo Ngwe et al. 2015). Wild genetic diversity shows greater yam originated in rainforests of Peninsular and Island Southeast Asia and/or New Guinea, from unknown wild progenitors (Mignouna et al. 2002). Greater yam domestication, like that of its relatives, is thought to have involved selection for reduced tuber toxicity (Lebot 2009). No traces of greater yam have yet been recovered from the African archaeological record. Unidentified parenchyma tissue has been found from a number of sites, such as Lyonda in DR Congo (c. 300 BP), Musanze IV and Mweru Cave (c. AD 1000) 
in Rwanda, and sites on Pemba Island off the coast of Tanzania from around 700 AD (Eichhorn and Neumann 2015; Giblin and Fuller 2011; Walshaw 2005), and if identification criteria can be developed it would be worth revisiting these to assess if they represent greater yam or other taxa like African yams, or taro.

\section{Sugarcane}

Archaeobotanical evidence of the domestication of sugarcane is currently absent, and while macroremains and possible sugarcane phytoliths from Yuku Rock shelter and Kuk Swamp in Papua suggest it may have been exploited from the mid Holocene, it is unclear whether it was cultivated (Bulmer 1975; Lentfer and Denham 2017). Modern genetics suggests sugarcane was domesticated in Island Southeast Asia and/or on the island of Papua, probably from S. robustum, a species confined to New Guinea and associated Melanesian islands. India and South China may have played a role in this process via natural hybridization with $S$. spontaneum, a much more widely distributed species that occurs across a wide region from some Pacific Islands through to parts of Africa (Castillo and Fuller 2010; Grivet et al. 2004). Although sugarcane is adapted to similar climates as banana, greater yam and taro, it differs in that its main importance throughout history has been as a cash crop, cultivated for export. It therefore may have spread on arteries of Indian Ocean commerce in an organised fashion, unlike the other Southeast Asian crops discussed above. Sugarcane is thought to have been traded in India for at least two thousand years. Records by a general of Alexander the Great's forces of a 'reed that gives honey without bees', apparently referring to sugarcane in 327 BC (Hannah 2000), make an early Indic diffusion into Africa possible (Gopal 1964). Tax records indicate that sugarcane was grown on the Euphrates by the 7th century AD, and it appears in Egyptian papyri from the mid-8th century. Some historical sources suggest a Persian introduction to East Africa before the 9th century (Watson 1983; Wigboldus 1994). Few studies have considered how sugarcane arrived in Africa, nor are there systematic surveys of African cultivar diversity that could shed light on this question. Early European accounts hint at its widespread use in the African humid zone in the 1600s (McMartin 1961). Desiccated sugarcane has been detected in the Islamic levels at Quseir al-Qadim in Egypt (van der Veen and Morales 2011). Historical records attest to sugarcane being present on Zanzibar from the 10th century (Watson 1983).

\section{Linguistics}

\section{The Possible Role of Linguistics}

Linguistic analyses, too, can crucially inform the history of food crops in Africa. The main potential use of such data is identified by Blench as:

a. describing patterns of loanwords that track the introduction and diffusion of new or innovative cultivated plants and animals, management techniques and related socioeconomic institutions; and, b. reconstructing individual lexi- 
cal items to a hypothetical proto-language that make it likely that they were known to speakers of that language (Blench 2006, pp. 14-15; 2007, p. 599).

Regarding the Asian food crops relevant here, Blench makes a particularly important point:

The dichotomy between cereals and vegetative plants is very marked: with cereals it is possible to compare and contrast linguistics and archaeobotany; with other crops, linguistics is presently the only tool available for reconstruction of their history. As a consequence, agriculture tends to be seen from a semi-arid perspective; better data on forest-zone crops might well transform existing models (Blench 2006, p. 203; Blench 2007, p. 607, emphasis added).

While Blench's statement overlooks the many novel archaeobotanical methods that are now available for studying vegetative crops, such as starch, phytolith, parenchyma and pollen analyses (Goude et al. 2019; Haberle 1995; Lentfer 2009; Mbida Mindzié et al. 2000; Power et al. 2015; Pryor et al. 2013), these have only rarely been applied in Africa to address the question of Asian crop introductions, and are plagued by methodological issues associated with poor preservation and uncertain taxonomic specificity. As such, linguistics remains a key method of enquiry.

\section{Inventory, Classification, and Documentation of Languages}

The major problem with using linguistic data to reconstruct crop histories in Africa is that the geographical area where the crucial transfer of imported Asian food crops took place is extensive and hosts a great number of languages. We focus in the following discussion on the intra-African diffusion for which we assume that the minimal area to be surveyed linguistically is the rainforest and its fringes. Figure 4 and Table 3 give a linguistic inventory of that area.

The difficulty of a linguistic evaluation arising from the sheer size and diversity of the specific geographical region is compounded by the fact that even basic genealogical classification of the languages has not yet been established conclusively. Table 3 presents the inventory of linguistic lineages to be considered for the area, namely two distinct lineages each with around ten, partly historically distant subgroups, and their number of member languages, together totalling c. 840. This outline is more conservative than Greenberg (1963) as it relies on genealogical hypotheses that are supported by publicly available evidence (see Güldemann 2018a, b for a more detailed discussion). In particular, it does not assume Greenberg's all-comprising Ubangi family, which implies that one needs to evaluate each constituent group of traditional Ubangi separately (we point in Table 3 to a more promising core, which is identified based on ongoing research by the second author). The genealogical diversity implies that a linguistic comparison, including a reconstruction of earlier crop terminology, needs to consider data from far more language groups than has been commonly envisaged.

Apart from the number of languages and their diverse classification, scholars are confronted with their deficient documentation and analysis. Moreover, the terminology to be ascertained should comprise far more than just single generic names for 


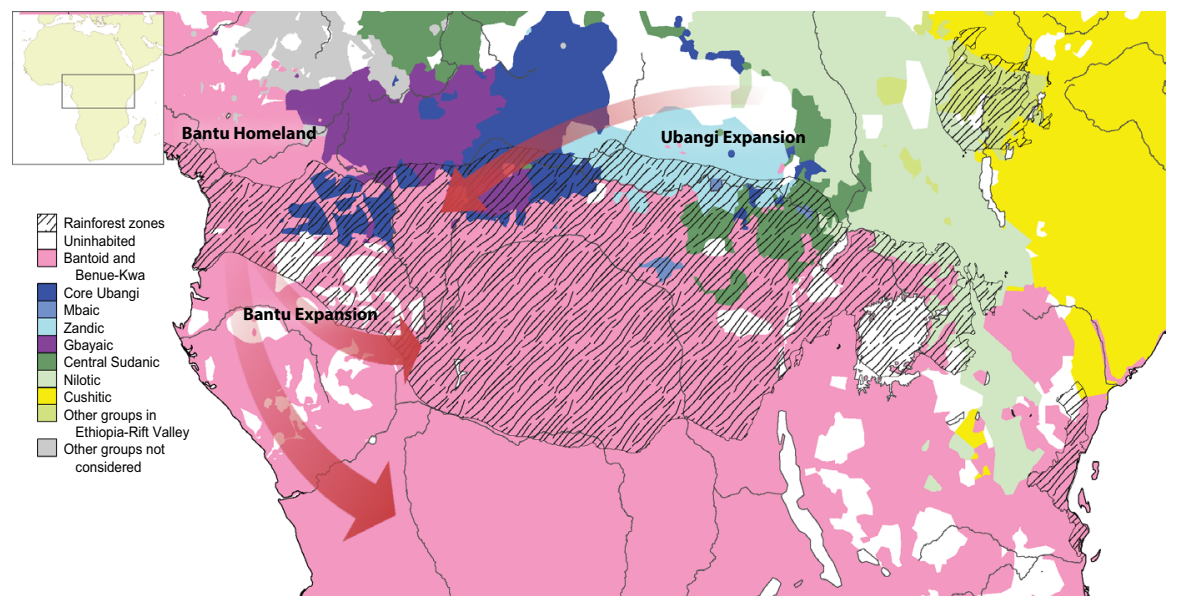

Fig. 4 Modern linguistic groupings that may have been involved in diffusing Asian crops in Central Africa

Table 3 Inventory of linguistic lineages to be considered in the African core region of Asian crop dispersal (with some data representation in selected publications)

\begin{tabular}{|c|c|c|c|c|c|c|}
\hline No. & Lineage & & $\begin{array}{l}\text { Number of } \\
\text { languages }\end{array}$ & Blakney (1963) & Rossel (1998) & Blench (2009) \\
\hline 1 & Bantoid-Bantu & Niger-Congo & c. 700 & c. 180 & Several hundred & c. 45 \\
\hline 2 & Mundu-Baka & & 13 & 2 & 3 & 1 \\
\hline 3 & Bandaic & & 16 & - & - & - \\
\hline 4 & Ngbandic & & 8 & 1 & - & 1 \\
\hline 5 & Ndogoic & & 5 & - & - & - \\
\hline 6 & Indri & & 1 & - & - & - \\
\hline 7 & Togoyo & & 1 & - & - & - \\
\hline 8 & Feroge-Mangaya & & 2 & - & - & - \\
\hline 9 & Mbaic & & 4 & - & 1 & - \\
\hline 10 & Zandic & & 6 & 1 & 1 & 1 \\
\hline 11 & Gbayaic & & 14 & 1 & 2 & 1 \\
\hline 12 & Bongo-Bagirmi & Central Sudanic & 39 & - & - & - \\
\hline 13 & Sinyar & & 1 & - & - & - \\
\hline 14 & Kresh & & 1 & - & - & - \\
\hline 15 & Aja & & 1 & - & - & - \\
\hline 16 & Birri & & 1 & - & - & - \\
\hline 17 & Moru-Madi & & 10 & 2 & 2 & 2 \\
\hline 18 & Lenduic & & 3 & - & 2 & - \\
\hline 19 & Mangbutu-Efe & & 7 & 2 & - & - \\
\hline 20 & Mangbetu-Asua & & 3 & - & - & 1 \\
\hline
\end{tabular}

Highlighted in italics promising core family of Ubangi 
the Asian food crops themselves. In addition, the analysis would preferably include the terms for the potentially multiple cultivars as well as for other items, notably similar wild or crop plants such as those listed in Table 1, because these may be the source for modern Asian crop names or may betray their earlier designation. However, we currently know very little about this broader vocabulary for the majority of the relevant languages.

The data problem becomes yet more severe if we consider on the one hand crossAfrican dispersal paths from a northeastern direction involving Sudan and the Horn of Africa, and on the other hand the potential entrance points of the various crops into the continent (see Table 2 and Fig. 4). Considering the northeastern zone we call here Ethiopia-Rift Valley makes the linguistic task immensely more complex, because this area hosts a yet greater linguistic diversity but it is one of the linguistically least known areas of Africa (see Güldemann 2018b). Taking coastal contacts into account requires careful analysis of some non-African languages, notably Malagasy (and its Austronesian relatives) and Arabic.

Looking at the previous studies that used linguistic data in the reconstruction of forest-zone food crops in Africa, none comes close to providing a sufficiently representative historical linguistic analysis. This is briefly exemplified in the three rightmost columns of Table 3 with reference to important contributions that have discussed the history of plantains and bananas in Africa; the situation there carries over to other relevant studies. It can be seen that most of the linguistic lineages that should be investigated with respect to the age of banana cultivation are underrepresented or entirely neglected, even in Rossel's (1998) otherwise extensive and meticulous survey of banana terminology. This holds in particular for lineages with small size and geographical dispersion, but these may in fact have been important in the past, until they were submerged by later language spreads. The opposite may apply to large groups possibly involving an expansion that is more recent and thus less relevant for early historical processes. Furthermore, the relevant figures give the number of lexical root tokens rather than of languages from a particular lineage, because all three works discuss several different potentially reconstructable banana words, so that some figures involve the multiple mention of a single language. Hence, the data deficiency recorded in Table 3 is even more dramatic than would appear from the figures, as the number of languages representing a given lineage is in fact lower. All in all, existing linguistic studies are characterized by an eclectic, non-representative selection of language data and prevent a methodologically robust linguistic reconstruction that could shed light on the historical depth of crop cultivation in all language groups and thus do justice to the complexity of the topic.

\section{Historical Linguistic Models}

Another major type of uncertainty in our current linguistic knowledge involves the hypotheses about the historical dynamics of the lineages involved and their associated population history. This holds in different ways for Bantu and non-Bantu families. 
The overall historical scenario for the Bantu family is relatively clear. At least since Greenberg (1972), there is general agreement about its origin in the border area of Nigeria and Cameroon. Moreover, the enormous success of the territorial and demographic expansion of Bantu-speaking peoples is commonly explained by some features of a food-producing subsistence mode, offering them certain advantages vis-à-vis other populations in newly colonized areas. The relatively advanced state of Bantu research has led, however, to a general bias toward this family. A Bantu bias not only holds for linguistic research in the narrow sense (see Güldemann 2018b) but also for non-linguistic approaches to population history. For one thing, there is the generalized assumption that Bantu-speaking peoples were the first food producers across the entire rainforest (cf., e.g., Vansina 1990). More recently, Blench (2009, pp. 375-376) has accorded Bantu a crucial role in the eastward spread of the Asian forest-zone crops, which is implied by his hypothesis about their initial, sea-borne introduction into western rather than eastern Africa. The available linguistic evidence does not so far conclusively support the exclusive importance of Bantu for agriculture in the rainforest, let alone its specific role in the dispersion of Asian crops. In fact, recent research on the Bantu expansion suggests that the initial south(east)ward migration phase, into and through the more southern humid zone, occurred within a partly savannah-like environment due to localized forest crises in western areas that today again have complete tree cover (Bostoen et al. 2013, 2015; Bostoen and Muluwa 2017; Grollemund et al. 2015; Maley 2002; Maley et al. 2018; Ngomanda et al. 2009), although some authors question this Savannah Corridor model (Bremond et al. 2017). In any case, the Bantu expansion was not obviously fuelled by a strong agricultural subsistence adapted to the rainforest.

Our knowledge of the non-Bantu languages and their historical role in the tropical zone is even more fragmentary. This is already clear from the above-mentioned fact that their classification is still uncertain, implying that any previous historical models cannot yet be taken for granted and be simply integrated in a multi-disciplinary approach to the topic at issue.

Central Sudanic is considered by specialists to be, if not a fully proven, a highly likely language family (Boyeldieu 2010; Boyeldieu and Nougayrol 2008). This hypothesis and Boyeldieu's (e.g., Boyeldieu 2009, 2016) extensive and careful historical assessment of Bongo-Bagirmi, the largest subgroup in the northwest, suggests, if anything, the following overall scenario for Central Sudanic. Its (south)eastern realm, which includes northeastern portions of the rainforest, hosts by far the greater diversity of the family and is the likely area from which the westward expansion of Bongo-Bagirmi emanated, implying an early presence in our area of interest (see Güldemann 2018a).

The prehistory of Greenberg's Ubangi family has been modelled linguistically by assuming an initial major expansion from the west to the east and subsequent dispersals of some groups back toward the southwest (Bouquiaux and Thomas 1980; Saxon 1982). Apart from the insufficient evidence provided by these authors, the major problem with this general scenario is that language specialists have not even replicated Greenberg's hypothesis of a unitary Ubangi (cf. Moñino, 1988: 18). In particular, such demographically major lineages as Gbayaic and Zandic are repeatedly excluded (see, e.g., the careful historical-comparative evaluation of Gbayaic by 
Moñino 1995, 2010). With respect to the remainder of Ubangi, the greater diversity lies again in the east around the wider border region of South Sudan, the Central African Republic and the Democratic Republic of Congo. Furthermore, to the extent that linguistically investigating lineage history is already possible, signs of recent colonization are particularly salient in the west, and/or point to an east-towest trajectory (cf. Cloarec-Heiss [1995, 1998] for Bandaic and Winkhart [2015] for Mundu-Baka). The expansion involves areas both in the north, which applies to Bandaic having apparently supplanted there the earlier spread of Bongo-Bagirmi from Central Sudanic, and, more important for the present topic, in the south, which holds for Baka, Bandaic, Ngbandic, and Mbaic and also involves the penetration of the rainforest.

In general, non-Bantu language groups not only bestride the northern fringes of the rainforest but also have members deep within it, whereby at least some of them appear to be relics affected by other spreads rather than reflexes of recent immigration, notably the Mangbetu-Asua and Mangbutu-Efe families from Central Sudanic and the Mbaic family and possibly some western Mundu-Baka languages from Ubangi. Moreover, the modern diversity profile of Central Sudanic and the core of Ubangi is so far best explained by an overall historical trajectory from the northeast to the southwest, which is further supported by possible signs of an old-age interaction in their assumed staging area northeast of the rainforest (cf. Güldemann 2017).

Overall, the Central African rainforest is thus an extensive dynamic frontier between two linguistic population groups-non-Bantu moving south and west, and Bantu moving first south but then also east and north-with the latter dominating in more recent history. Most relevant language groups have a modern profile that is compatible with an early presence of food production in the respective population. Although historically diagnostic methods need to investigate all groups more systematically, this means that Bantu cannot be the only possible source of food producing subsistence. In view of this observation, and projecting the above historical dynamics on to the present question, there is every reason to test with linguistic methods a hypothesis that so far has never been systematically engaged with. That is, rather than assuming that Bantu is the key for reconstructing the dispersal of Asian crops across Central Africa, non-Bantu food producers emanating from the east along the northern edge of the Central African tropic zone probably played a crucial, and possibly earlier, role in this process.

\section{Modelling the Crop Suitability of Asian Crops and the Spread of Food Producers}

Extant archaeology data on the expansion of food producing societies across the African continent can allow a spatial understanding of corridors of Asian vegetative crop dispersal. To reconstruct tentative corridors, we mapped calibrated radiocarbon dates of archaeology sites associated with food producers during four time intervals that are important for the arrival of vegetative crops (6000-4500, 4500-3000, 3000-1500 and 1500-300 BP: Online Resource 1 and 2). Dates were compiled using existing databases and published sites (Oslisly et al. 2013; Russell et al. 2014; 
Seidensticker 2016). Although this analysis is not exhaustive of dated food producer sites, our data aim to show most dated sites in these regions. The analysis excludes sites associated with ambiguous food producer traditions with high levels for foraging, such as Kansyore, because of the uncertainty over the presence of agriculture. The results show the deep history of food producers in NE Africa (Fig. 5).

Combining these data with crop-suitability maps, based on ecological parameters, can allow further refinement of likely dispersal routes. To explore regions that would have been ideal for fostering cultivation of Asian crops, we sourced key determinates of successful rainfed banana, taro, greater yam and sugarcane cultivation (Online Resource 1). We then spatially assessed their suitability across the continent using modern-day climate conditions (Fig. 6). Although we do not consider Holocene climate change, we do not expect this to considerably alter these models, given that it primarily related to length of droughts and all of the Asian vegetative crops exhibit some drought tolerance (Online Resource 1). As with the archaeological data, the Horn of Africa in the northeast again appears to be a plausible candidate area for crop dispersal.

\section{Discussion}

\section{The Different Dispersal Routes}

Tropical Asian crops impacted African life in multi-faceted ways. Due to their unique climate preferences, the appearance of greater yam and taro allowed food production in a wider range of climates than African domesticates alone. Importantly, banana and sugar cane provided a reliable source of energy all year round in both non-intensive and intensive farming systems with low human input, and low risk of loss through pests. The resulting foods, the plantain/banana and cane pith, are edible with no more than brief roasting, or mastication in the case of sugar cane, unlike cereals, which require laborious processing and the facilitation of storage as they are seasonal crops. The transformative impact that the adoption of Asian crops must have had on prehistoric African societies can be modelled with the comparative case of the Yanomami people of the Upper Orinoco Valley in South America. This area provides a firmly dated example of banana introduction in an environment highly analogous to Central and Western Africa. In this case study, banana, adopted after Columbian contact, became the overwhelming dominant crop and is credited with a population explosion that shaped Yanomami and other peoples in the Amazon Basin (Divale and Harris 1976; Smole 1976). For Africa, it is unlikely that the population densities encountered historically in the Congo Basin and the interlacustrine zone could have been supported without the adoption of the Asian food crops.

A major challenge for archaeologists, geneticists, linguists and other researchers has been to reconcile the disparate and often indirect datasets for Asian crops in Africa, in order to reconstruct their dispersal histories across this continent. Multiple lines of evidence hint that the spread of Asian crops into Africa was very complex. This process was perhaps substantially later than entertained in several 

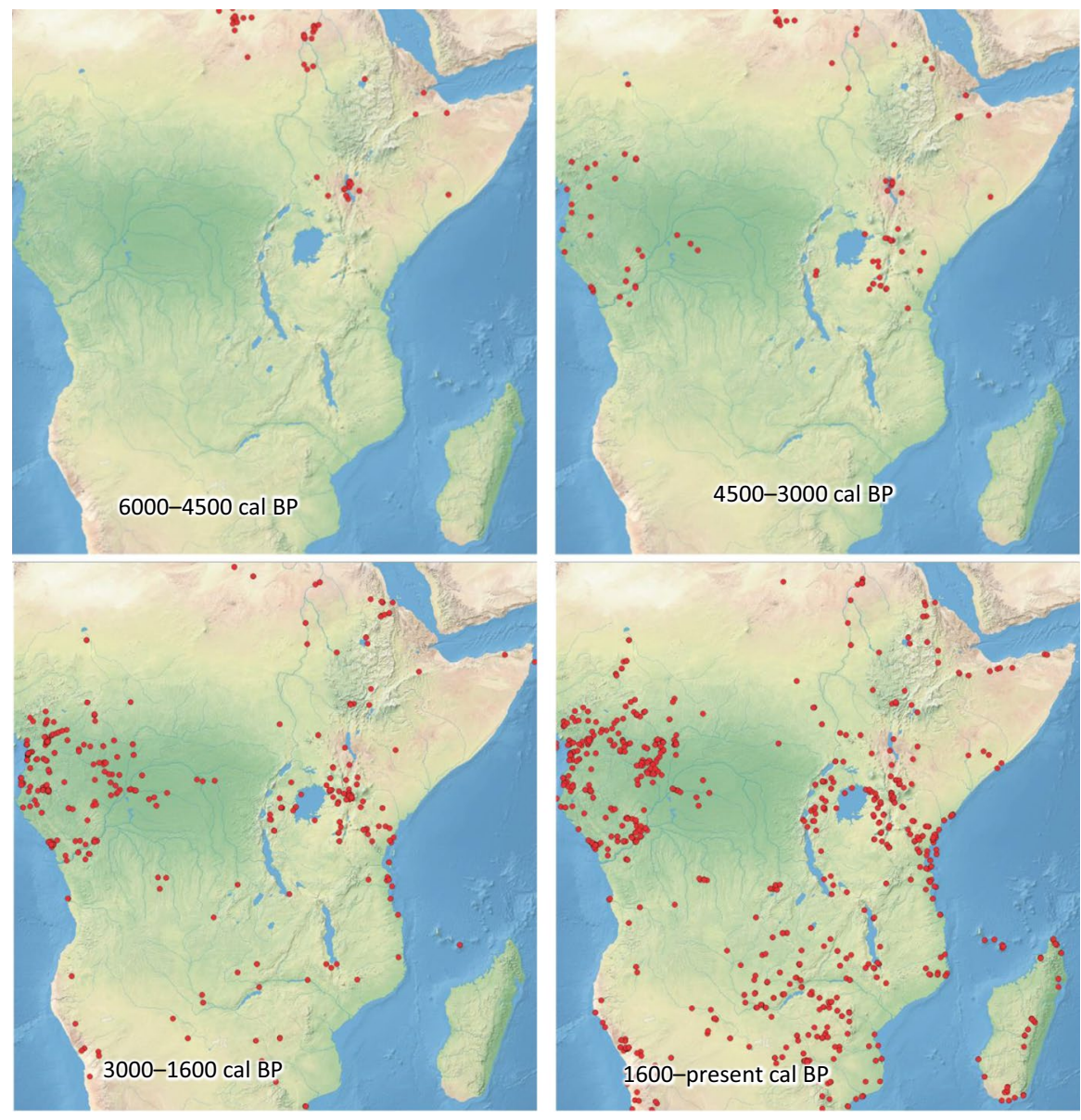

Fig. 5 The spread of food-producing associated archaeological sites indicates that an early or late Asian crop arrival scenario is possible. Gaps in site density such as in the Congo Basin, the Northern Forest Margin and the Horn of Africa relate to the rarity of fieldwork in these regions and not necessarily an absence of settlement. For full details see Online Resource 1 and 2

commonplace scenarios. Although we cannot yet reconstruct precisely how these crops spread to Africa, we can propose routes that are compatible with existing evidence and outline a pathway that future fieldwork should target.

The history of the Asian crops has previously been oversimplified, with the predominant interpretation that they arrived in Africa as a package. However, given the distinctiveness of each of these crops, we would argue that this is unlikely. Rather than being simply 'hot and humid' crops, they have partly distinct climatic requirements shaping their dispersals (Fig. 6). Even without them (the early agricultural expansion in Cameroon and West Africa lacked the Asian complex), there was more than one African 'tool kit' that allowed expansion into tropical regions. African domesticates such as white and guinea yam, enset, 

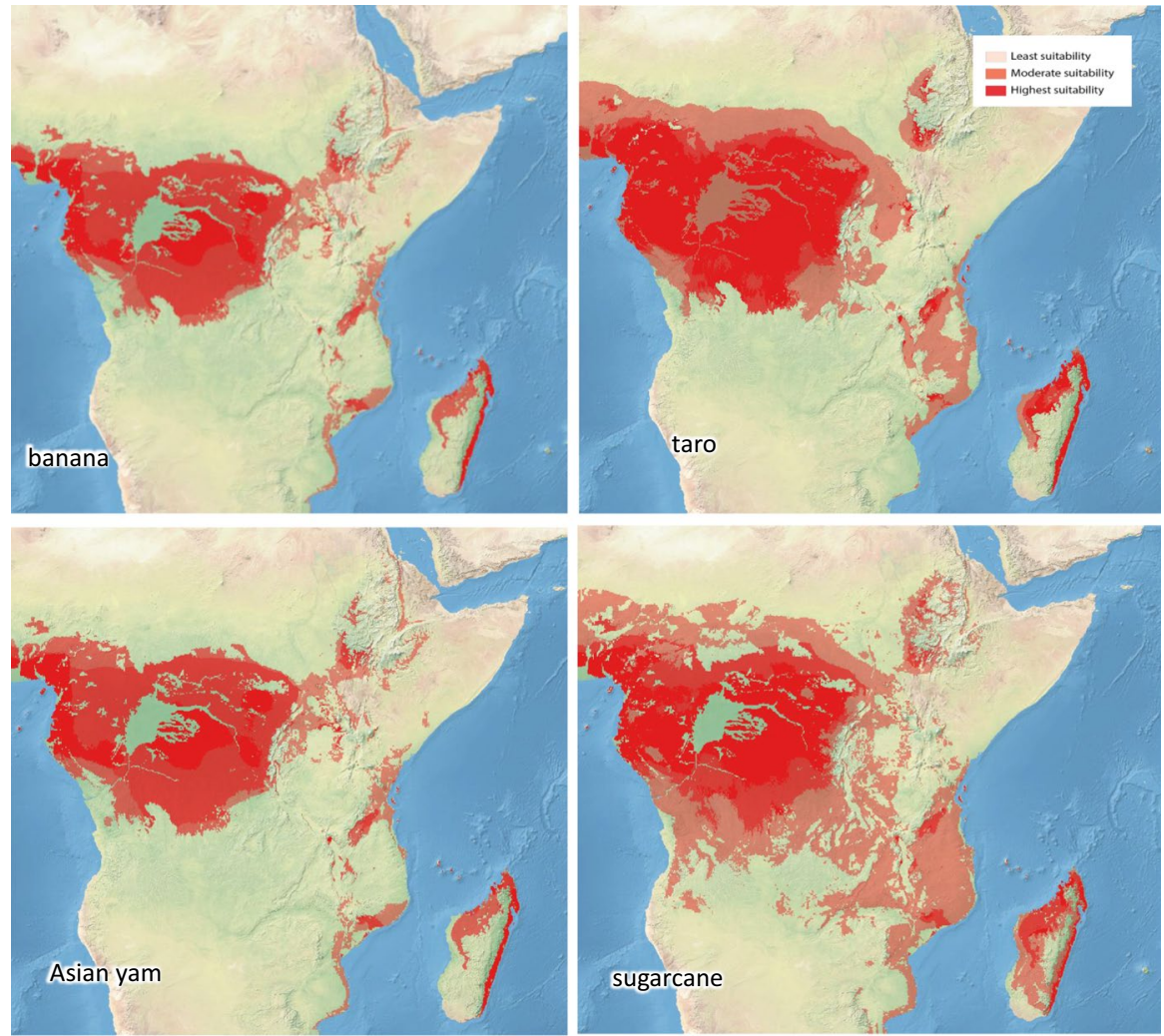

Fig. 6 Ecological suitability for rainfed cultivation of each of the main four Asian crops. Darker colour shades represent higher suitability. Suitability calculated based on parameters detailed in Online Resource 1 (Color figure online)

Hausa potato, yam bean and so on involve traditions that are partly independent both from the Asian crops and from each other. Thus, we propose that the Asian crop history should in the first phase be investigated for each crop separately.

Based on the above bio-geographic, archaeo-historical and linguistic survey, we discuss in the following the four major routes proposed for the Asian crop dispersal into and within Africa given initially in Table 2 and repeated in more detail in Table 4 and Fig. 7. Of the four Asian crops, in this synthesis we pay particular attention to the history of banana due to the breadth of evidence. The general sequence is viewed as follows. Reports of high AAB cultivar numbers in Central Africa and early banana phytoliths in Cameroon have been hugely influential in popularising the idea that AAB banana appeared in Africa by at least $1000 \mathrm{BC}$ (Table 4). This was then followed by a second wave bringing the East African Highland banana (AAA), and finally a last wave bringing AA, new AAAs, ABB and new AABs (Blakney 1963; De Langhe et al. 1995; Perrier et al. 2011; Rossel 1998). The East African Highland banana appears to have an origin separate from 
$\mathrm{ABB}$ and arose from a single hybridization event, presumably in Asia (Kitavi et al. 2016).

\section{Route A: Atlantic Ocean Route}

Evidence of banana phytoliths in Cameroon dating to 700-320 cal BC and the concentration of evidence of early banana in West and Central Africa (cultivar number) seems to be contradicted by the lack of supporting evidence of an AAB banana genetic legacy in East Africa, where its initial arrival would presumably have occurred (De Langhe et al. 1995). In order to reconcile this contradiction, authors have suggested a direct establishment of Musa, and potentially taro and greater yam, by maritime peoples who were capable of sailing around Africa and reached the Atlantic coast in West Africa. Proponents have cited musical traditions in support of this route (Blench 1996, 2009; Jones 1964, 1972). An Atlantic route is, however, untenable, we argue, as there is currently no indication that such extensive early maritime networks connecting the Atlantic and the Indian Oceans existed.

\section{Route B: Indian Ocean Route}

The more common theory is that the Asian crops moved from Southeast Asia across the Indian Ocean to East Africa. This approach is the bedrock of the dispersal route proposed by Murdock (Route B1). He suggested that banana and other Asian crops found in Africa today entered the continent via the East African Coast (Murdock 1959, 1960). He argued that coastal 'Megalithic Cushites' may have adopted these crops and spread them inland until they reached early Bantu populations, who later spread them across sub-Saharan Africa. However, this theory had no grounding in the actual distribution of early food producers in eastern Africa.

An East African dispersal, if not mediated via Arabia, where a Circum-Indic route is possible, involves a direct transportation across the Indian Ocean, and one such hypothesis commonly sees banana and other crops diffuse into Africa from Madagascar (Tables 2, 4). From as early as the turn of the 19th century, researchers have pointed to Madagascar's colonisation by Austronesian-speaking people from Southeast Asia as a likely source of Asian tropical plants in Africa (Johnston 1904b; Price 1995; Simmonds 1962). Malagasy people cultivated Asian crops from at least AD 730, including rice and cotton. Presumably these crops were brought directly from Southeast Asia about 1500 years ago during the initial Austronesian colonization of Madagascar (Crowther et al. 2016). On the humid eastern coast of Madagascar, banana, taro, greater yam and sugarcane were probably cultivated from an early date (Pomerantz 2017). Yet the number of AAB banana cultivars in Madagascar is low (De Langhe et al. 1995) and their genetic heritage from M. balbisiana may suggest genetic input from its natural range such as eastern India, Indo-China, South China or the Philippines (Perrier et al. 2011).

There are scattered relicts of banana diversity that suggest some cultivars were introduced via the Swahili Coast (Route B2). Pemba Island off Tanzania and NE 


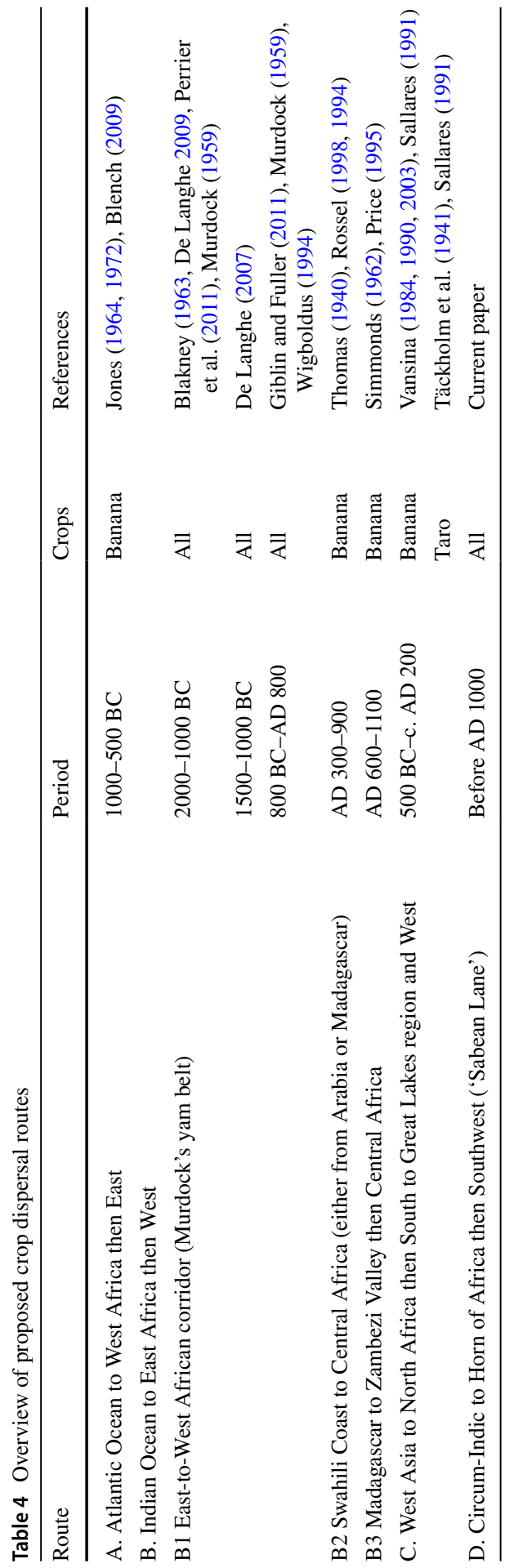




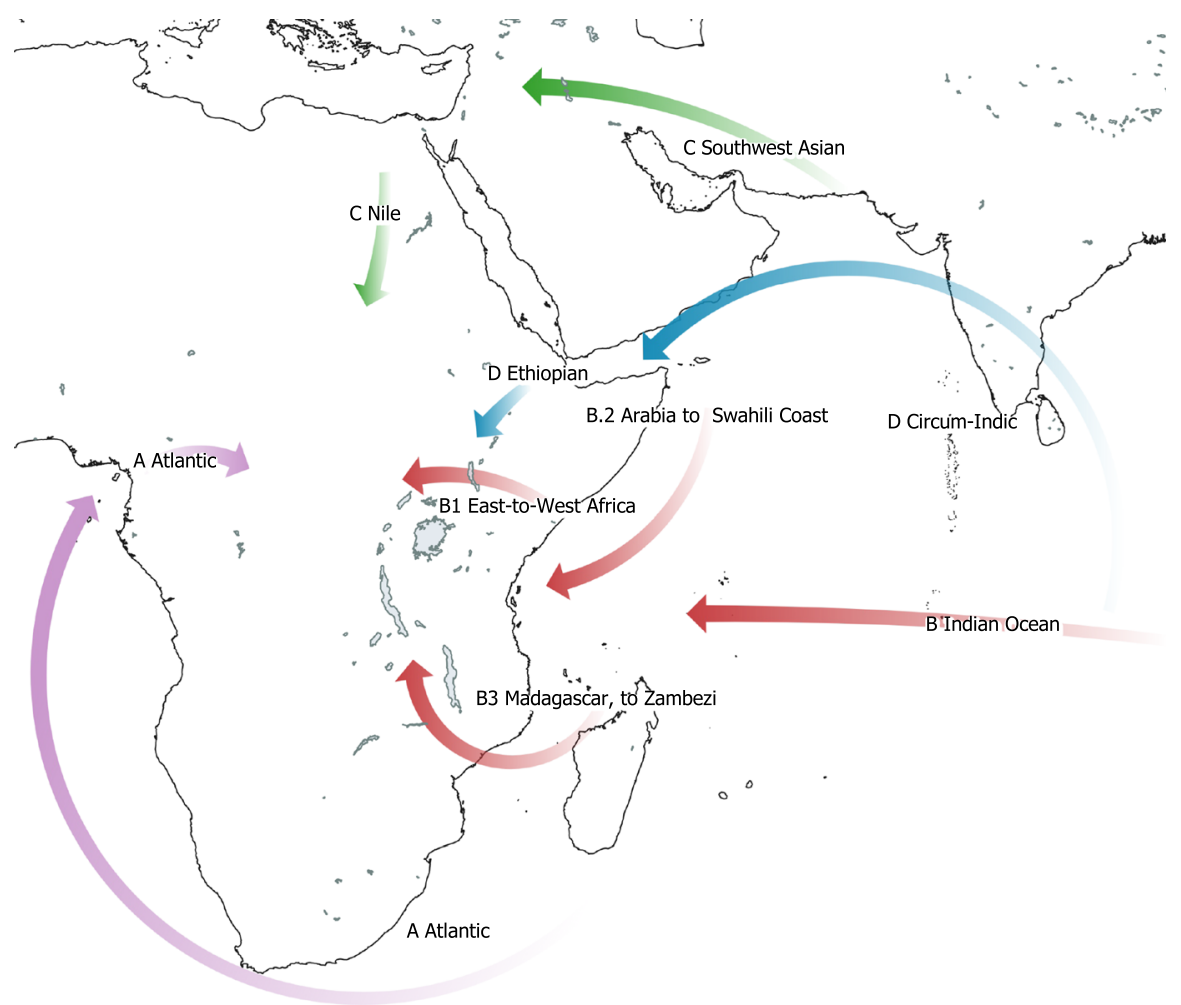

Fig. 7 Proposed dispersal routes of Asian tropical crops into and within Africa

Madagascar form a centre of banana diversity with Africa's only populations of non-sterile banana, seedy M. acuminata. Pemba's seedy populations exhibit Indonesian phenotypes. Aside from these two populations, relicts do not exist anywhere in the western Indian Ocean. It could be envisaged that, had AAB cultivars been introduced via East Africa, they would have died out long ago in its semi-arid landscape, but fieldwork in Oman shows that reservoirs of diversity can persist in dry environments hostile to banana (Buerkert et al. 2009). Due to their phenotypes, distribution and seediness they are the clearest evidence of a direct introduction from Southeast Asia (De Langhe 2009). As seedy M. acuminata has marginal food value, its enigmatic presence in the western Indian Ocean probably represents an accidental introduction.

A Madagascar dispersal is a complicated route involving two major possibilities: the first sees them travel north from Madagascar to the Swahili Coast of Tanzania and Kenya, and the interlacustrine region (Route B2), and the second from Madagascar across the Mozambique Channel, to the Zambezi Valley and into either Zambia or the southern Rift Valley (Route B3). In the second scenario, the stretch of the southern Indian Ocean coast along Central Mozambique is crucial as this area is more suited to cultivation of tropical crops than the rugged 
plateau region of northern Mozambique and the expanse of more arid lands in south Mozambique (Fig. 5; Simmonds 1962; Price 1995). However, little data is available on the prevalence of food producers in the area (Fig. 6), and a rapid spread of tropical crops is unlikely if food-producing societies were absent. The alternative scenario- that Asian crops spread from Madagascar to a more northern corridor via the Swahili Coast-has stronger support, given that crop-raising societies were probably present on the Swahili Coast earlier than on the central Mozambique Coast to the south, due to their origin in the north. Nevertheless the earliest history of East African crop-cultivating communities is still poorly known and early examples of cultivation such as at Mikindani in southern Tanzania have produced only small numbers of plant remains (Crowther et al. 2016; Pawlowicz 2011). Linguistic evidence provides an unclear and partly controversial picture, but at least Malagasy words for 'banana' and 'millet, sorghum' are agreed to be of Bantu origin, which casts doubt on the assumption of a simple event of unilateral crop transfer from Madagascar to the East African coast (Adelaar 2009, 2016; Beaujard 2011). Given that pearl millet and sorghum agriculture were present in Southern Africa from the 10th century and possibly the 2nd century AD, societies familiar with plant cultivation were widespread along the entire southern Indian Ocean coastline for over a thousand years (Denbow and Wilmsen 1986; Klapwijk and Huffman 1996; Maggs 1994).

Both of these routes involve farmers or traders carrying banana suckers and seed tubers and corms across extensive unsuitable areas and into the continent's interior because both regions are marginal for tropical crops (Fig. 7). It is unclear if we can expect a time lag before early Bantu farmers, with Sahel systems cultivating pearl millet, sorghum, finger millet and cow pea, adopt vegetative crops and transport them inland across marginal environments where they do not grow today. As outlined, both models imply a late introduction to Africa, refuting evidence at Nkang. Consideration of the weight of evidence makes a late introduction seem likely. A late introduction explains why Asian rice, a major crop in Southeast Asia, seems not to appear until much later (Blench 2007). Vansina has argued that, in Africa and South Asia, sterile banana diversity correlates with the importance of banana in local agriculture (Vansina 2003). Cultivar diversity may be more related to the intensity of human plant management over the last few centuries than to the age at which a crop was cultivated. The areas of the highest banana diversity, the Congo Basin and the Great Lakes Region, are the primary centres of banana production in Africa. Although an Austronesian-mediated dispersal via Madagascar is too late for the Nkang evidence, it may be early enough for reaching Mbandaka by AD 1330 (Fig. 4). The final problem with this route is that all available archaeobotanical surveys of the Swahili Coast (c. AD 650-1200) show that early farmers there used African Savannah crops (i.e. pearl millet, sorghum, finger millet and cowpea) and few if any tropical Asian crops. The rarity of Asian crops on these African archaeological sites, even though they appear on contemporary Malagasy sites (c. AD 650-1200), suggests that there was little cultural exchange and few crops moved from Madagascar to East Africa during Madagascar's early history (Crowther et al. 2016). This argues against Madagascar being a staging board for the spread of Asian cropsparticularly AAB banana-into Africa, although we cannot rule out the possibility 
of pre-Madagascar Austronesian settlements playing a role. Yet at this point Austronesian East Africa settlements that pre-date the Austronesian settlement of Madagascar are speculative. Given the contact highlighted and the possibility that banana and taro were rare or absent on the East African Coast until approximately the 7th century, we suggest that the Swahili Coast region probably played only a secondary role in the diffusion of these crops into Africa. It could have contributed some of the minor diploids and triploids found today along the East African Coast, while the Pemba and Madagascar seedy banana are probably direct introductions from Southeast Asia, where the nearest seedy populations are found.

Some have hypothesised that tropical crops could have arrived by 2000-1000 $\mathrm{BC}$, long before any evidence of crop cultivation in East Africa has been detected. De Langhe (2007) suggests that no agricultural population was necessary to transmit banana, taro and greater yam cultivation c. $1000 \mathrm{BC}$, as semi-agricultural foragers might have adopted these crops and diffused them to the humid zone of Central Africa. Today, banana cultivation is indeed practised by some African tropical foragers. The Baka people in Cameroon gain a large portion, if not most, of their diet from the bananas they cultivate. Banana is favoured because, unlike other crops, it copes with periodic abandonment during foraging forays out of camp (Kitanishi 2003). In addition, Baka engage in low level establishment and tending of indigenous yam stands, a food provision strategy that appears to have a longer history than banana cultivation (Sato 2001; Yasuoka 2013). This has an analogy in the ethnographic record of Australia, where forager tuber harvesting is credited with encouraging tuber growth (Hillman 1989). However, the Baka evidence is questionable, as detailed ethnographic work indicates that their banana cultivation only commenced in the 1950s (Kitanishi 2003) and their yam use involves an indigenous species that is not dependent on humans. Overall, ethnographic records provide few examples of the spontaneous adoption of crops by foragers. It seems unlikely that tropical foraging groups, which are highly mobile, would spontaneously adopt the cultivation of a sterile exotic crop, fully dependent on humans for survival, without being culturally engulfed or even assimilated by food producers. Furthermore, a forager dispersal theory requires that this process occurred innumerable times at explosive speed across the Congo Basin for the crop to be spread to Cameroon. If this process of dispersal did occur, it more likely occurred slowly and involved greater yam or taro, as they have local analogues, and even then, probably only after intense contact with food producers.

\section{Route C: West Asian Route}

Some of the earliest research on the topic suggested Asian crops reached India before Africa and moved to Northeast Africa, spreading south along wet environments of the Nile Valley (Sallares 1991; Täckholm et al. 1941; Vansina 1984, 1990). A Nile route would mean that the Asian crops reached Sudan early on and gradually spread into sub-Saharan Africa to the west of the Ethiopian Highlands and Lake Turkana. They may have become less restricted to river habitats by the time they reached the White Nile in Equatoria, and gradually moved into the interlacustrine 
region and the Congo Basin (Grimaldi 2016; Johnston 1904b; Täckholm et al. 1941; Vansina 1984, 1990, 2003). Once in the tropical rainforest or monsoon climatic zones, it can be envisaged that these crops once again spread along river corridors as farming societies in this environment tend to be tied to riparian zones. A Nilebased route has been popular because archaeobotanists have found Africa's earliest crop cultivation in the Nile Valley, and because taro and banana are of importance in recent Egyptian agriculture. Although the Nile Valley is not a tropical environment, river water allows these crops to grow in this region. However, there is so far relatively little evidence of the Nile being a corridor of crop exchange, and African domesticated cereals appear in Egypt remarkably late (van der Veen 2011). The lack of historical, pictorial or archaeobotanical Egyptian evidence before AD 900 of any of these crops, means that a Nile dispersal is unlikely to pre-date Late Antiquity and rules out an early introduction over 2000 years ago.

\section{Route D: Circum-Indic Route}

The dispersal route with the shortest sea crossing is the Circum-Indic Coast, involving the so-called 'Sabean Lane', and the archaeobotanical and historical evidence of the Asian crops in India is early enough to support this route. Although archaeological fieldwork along much of this corridor is sparse, there is data from arid NE Ethiopia, which could have been an initial African bridgehead, showing that early cultivation and diverse Red Sea trading networks have existed for thousands of years, supporting a dispersal via Ethiopia. Although this corridor passes by many arid regions, all of the plausible dispersal routes involve stretches of such environments (Fig. 6). Once Asian crops could pass this habitat, they may have been cultivated in a major corridor on the southern and eastern Ethiopian escarpments. Asian crops would easily merge into the indigenous humid farming systems that are thought to have already been present in this region (Brandt 1996). Although it is not known when humid agriculture farming traditions commenced along the Ethiopian escarpment, the region does show the currently earliest agriculture in sub-Saharan Africa at c. $500 \mathrm{BC}$, and relatively early pastoralism from 1500 BC (Boardman 1999). An unspecific Musaceae leaf found at Kumali dated to two thousand years ago may hint that enset or banana was already important by the time Asian crops may have begun to diffuse through Ethiopia (Hildebrand et al. 2010).

We argue that a Circum-Indic coastal route from India through Arabia has currently the most explanatory power. Crop exchange between Africa and Arabia/ India is likely to have been frequent, given the early appearance of Asian domestic animals in Ethiopia by the 9th century BC (Fuller et al. 2011; Woldekiros and D'Andrea 2017). Exchange along this corridor in fact long pre-dates this time, as such African domesticates as sorghum, pearl millet and hyacinth bean (Lablab purpureus) are recorded in charred seed assemblages in India as early as the second millennium BC (Fuller 2003; Fuller et al. 2004; Manning et al. 2011).

A Circum-Indic coastal route implies that the tropical Asian crops, following domestication, slowly diffused west along different paths from approximately the mid-Holocene. As these crops would have moved from eastern India westward, 
they left the tropical zone and became cultigens in wadis and riverbanks and slowly reached northwest India, southern Arabia and then the African continent around the Horn of Africa. As they spread on to the humid and warm Ethiopian Highland escarpments, their spread would have become more rapid and converged in southwest Ethiopia, which is a region of diverse traditions of pastoralism, agropastoralism, horticulture, and intensive agriculture. Although vegetative-based cultivation in southwest Ethiopia is poorly studied, it has been proposed that it is ancient and predates the plough-based cultivation of cereals that is typical in the Highlands (Brandt 1996; Ehret 1979; Kanshie 2002). As Asian vegetative crop use by local non-Bantu farmers expanded, a relatively rapid dispersal through Africa is possible, reaching the northern margin of the humid zone and eventually becoming established on the Atlantic coast of West Africa hundreds, rather than thousands, of years before the Portuguese first glimpsed the coast. In the tropical regions of southwest Ethiopia, Guinea yams are a traditional feature of agriculture (Hildebrand 2009). However, this is not observed in much of the Congo Basin, suggesting that the northern forest margin is a dynamic region with a longer history as a corridor for crop dispersal than the Congo Basin. The presence of sucker-propagated enset corm subsistence in this area may have offered a native analogue for the rapid adoption and later spread of banana into South Sudan and further south into the Congo Basin and west towards the Gulf of Guinea. One of these dispersals took the ancestor of the East African Highland banana into the Great Lakes region, on to the Ugandan Plateau and the Ruwenzori Mountains. In this region, banana diversified and became the economic bedrock. The coalescence of banana and cattle is linked to the formation of social stratification and proto-kingdoms in the region from AD 800 (Schoenbrun 1993). Although the vegetative crop complex probably did enter part of the Congo Basin during the Bantu expansion from present day Cameroon to the Lower Congo and then follow the river upstream, it also likely entered the Congo Basin from the Great Lakes region, carried by non-Bantu Ubangi and Central-Sudanic speaking farmers.

\section{Conspectus}

Spatial analysis of the distribution and chronology of food-producer sites in Central Africa gives limited insight into when and how such societies spread. Although we know a lot about early village sites in Gabon, the Republic of Congo and Cameroon, in crucial areas in the Horn of Africa, the Congo Basin and in the Sahel to the north, fieldwork remains rare; this should not be misinterpreted as evidence for the absence of food-producing societies (Fig. 6). Nonetheless, the data is complete enough to show that from c. 2500 BP food-producing societies existed in a northern and southern belt around the Central Africa rainforest that could have transferred Asian crops (Davies 2014; Robertshaw and Mawson 1981). The northern belt could well have been a thinly populated region, inhabited by predominantly pastoral people, but it was at least periodically also inhabited by cereal- and tuber-cultivation-based societies (Grollemund et al. 2015). Thanks to the existence of early food producers along the northern and southern routes around the rainforest, foragers practising paracultivation are not needed to explain the diffusion of crops (see Fig. 5). If 
hunter-gatherers helped to spread these crops at all, it most likely involved greater yam, given that there is an analogue tradition of foraged wild yams all over Central Africa, and no such tradition with bananas.

Although we do not propose a date when Asian crops first appeared, the late dispersal model that we present could help explain why studies in Central Africa, including the Congo Basin and the Swahili Coast of East Africa, have failed up to now to recover more early banana phytoliths (Online Resource 1) (Eichhorn and Neumann 2015; Heckmann 2011; Kahlheber et al. 2014b; Neumann et al. 2012)

If Asian crops are relatively young in Africa, it raises the question of how these crops became so important in so many facets of life in the African tropics. Banana even commonly feature in the lore of rainforest foragers who do not practise cultivation (Turnbull 1965). One could argue that the role of banana in African ritual and cultural life is clear evidence of its status as an ancient crop in Africa, but this ritualization may occur rapidly (Warnier 1985), or may have been transferred from enset (Rossel 1998). The speed with which banana has embedded itself in Amazonian society after its introduction is seen with the Ese-Eja of the southwestern Amazon basin, who referred to banana and no other plants in their creation story, even though banana had been present in the region for just 350 years (Alexiades 1999). Furthermore, in most African regions Asian crops seem to play a smaller role in ritual life than African yams in the ritual life of West Africa.

A late arrival of Asian crops (after c. AD 400) does not preclude these crops having played an important role in the expansion of farming populations in the humid zone. Ceramic and linguistic evidence show major population movements have occurred relatively recently in the Congo Basin, and some expansions may be related to a final proliferation of banana, taro and yam cultivation, such as the Bondongo ceramic expansion AD 1000-1400 (Wotzka 1995). This crop dispersal model raises the question of what crops were in use during the initial advent of farming in tropical areas c. $1500 \mathrm{BC}-100 \mathrm{BC}$ in the Congo Basin and in the other regions of hot humid forest, such as the Ethiopian Escarpments (Livingstone Smith et al. 2017; Wotzka 1995). It is clear that pearl millet was utilised alongside elemi and oil palm (Kahlheber et al. 2009; Kahlheber et al. 2014a; Neumann et al. 2012). Some palaeovegetation reconstructions show climatic conditions from 1000 to $500 \mathrm{BC}$ were optimal for cultivating the Savannah crops pearl millet and cowpea (Ngomanda et al. 2009). Charred remains of savannah crops like pearl millet and cowpea appear during this period in both drier areas, as well as in the more humid conditions of the Inner Congo Basin, where they would be impractical as a staple crop. Indigenous African yams (yellow Guinea yam and white Guinea yam) are labour-intensive staples but are high-yielding and may have played an important role (Asiedu et al. 1997), but oddly, no trace of Guinea yam can be found in recent Central African ethnographies (Burkill 1939). Their use is confined to West Africa, Southwest Ethiopia, and pockets of East Africa and Madagascar. Other crops such as yam bean tuber, a likely local domesticate of Central Africa, and wild yams may have added a carbohydrate component to an economy based on cultivation of tree resources and fish (Potter and Doyle 1992).

These staples, like most forest fruit and underground storage organ crops, are low in protein and fat, unlike cereals, which often accompany pastoralism. The absence 
or rarity of livestock in this expansion into the forest compounds the lack of protein and fat in a carbohydrate-rich diet (Inglett and Charalambous 1979; Villareal 1970). Oil- and protein-producing arboriculture involving oil palm and African elemi must have been crucial. Oil palm is a light-demanding forest pioneer and it undoubtedly expanded its range as farmers cleared forest land from their riverine hubs. Nutritional limitations heightened the importance of fish, oil palm, nuts such as elemi, and domestic stock, but many of these resources could have only been regionally available. That is, fish are only abundant in rivers and on the coast. Oil palm, greater yam, and elemi do not grow in wet soils or dense forest (Maduelosi and Angaye 2015). Only small-scale goat husbandry has been historically practised in the humid zone, and since its productivity is hindered by disease and thermal stress, it is low intensity (Gifford-Gonzalez 2000; Kellman and Tackaberry 1997; Van Neer 2000).

When Asian crops did arrive, they allowed forest farmers to be freed from some of the labour constraints associated with Guinea or wild yams and produce abundant carbohydrates. The adoption of Asian crops did not remove the ceiling on protein and fat production, which restricted dense human settlement to riverine areas. Yet it did allow reallocation of labour for trading, collection and production of lipid and protein foods such as fish, goats or wild crops, and the work of opening land from the forest. This transition inevitably led to a higher farmer population density. This process of crop introduction and population increase in Africa would be repeated with the introduction of American crops in the 1500s. This presumably created another later population expansion until about the 1850s, when wars and colonialism led to population collapses (Morin-Rivat et al. 2017). The passage of time has not radically altered these dynamics, and to this day, human density away from river areas is extremely low in the Inner Congo Basin, although more recently, settlement and commerce clings to roads rather than rivers.

\section{Conclusions}

The evidence discussed above suggests several conclusions that point to a need to redirect the focus in research on Asian crop dispersal in Africa. First, there has been too much emphasis on early archaeological evidence for banana like the Nkang phytolith find, whereas banana and other Asian crops probably spread much later, perhaps not reaching the western side of Africa until around a thousand years ago. Moreover, too much attention has been paid to the hypothesis of the crops dispersing as a package, despite their distinct histories and the presently limited overlap of their growing ranges. In terms of dispersal routes, biogeographic evidence is compatible with banana AAB and AAA as well as other crops arriving in Central Africa via southern Arabia through the humid highlands of southwest Ethiopia, while also moving north and south along the Red Sea coast. Red Sea evidence of banana, taro and sugarcane means that it is possible that these crops arrived approximately contemporaneously, but it is unwise to assume that this is likely (van der Veen and Morales 2017; Woldekiros and D'Andrea 2017). Using linguistic evidence to address these issues is complicated by the enormous language diversity in the most important regions. Nevertheless, the evidence suggests that there has been undue 
attention paid to the Bantu expansion and too little to non-Bantu language families of the northeast tropical region that could be associated with the initial agricultural expansions in the region. Last but not least, much of the uncertainty about how and when these crops arrived and spread in Africa can be attributed to the low amount of archaeological research and the absence of fieldwork targeting these crops-especially, as it appears, along the Sabean Lane and associated regions, where the crops may have been cultivated for the longest period of time. Long-term campaigns of identification and dating of early agricultural occupation that combine sediment and dental calculus with microbotanical and linguistic studies in the humid corridors in the northeast of the Democratic Republic of Congo, the Central African Republic, South Sudan and Ethiopia should inevitably illuminate the complex history of these crops.

Acknowledgements Open access funding provided by Max Planck Society. We are grateful to Christfried Naumann for crucial assistance with producing Fig. 4. We thank the following for the generous support with site interpretation and comments: Barbara Eichhorn, Xue-Jun Ge, Xavier Pierre, Angélique D'Hont, Bernard Clist, Hans-Peter Wotzka, Ruth Tibesasa, Katharina Neumann, Steve Goldstein, Medhanit Tamerat Asmare, Alemseged Beldados, Jed Kaplan, Richard Oslisly, Kathryn de Luna, Achille Biwolé, Matthew Curtis, Louise E. Iles, Catrien Van Waarden, Marco Madella, Cecily Bourdillon, Marjaana Kohtamak, Luke Kirkwood, Alfredo González-Ruibal, Catherine D’Andrea, James Denham, Andre Strauss, Shira Gur-Arieh. We thank Cristina Zickert for assistance with figures. This research is funded by the Max Planck Society and ERC Starting Grant project 'FoodTransforms: Transformations of Food in the Eastern Mediterranean Late Bronze Age' (ERC-2015-StG 678901-FoodTransforms) directed by Philipp W. Stockhammer and funded by the European Research Council.

Open Access This article is distributed under the terms of the Creative Commons Attribution 4.0 International License (http://creativecommons.org/licenses/by/4.0/), which permits unrestricted use, distribution, and reproduction in any medium, provided you give appropriate credit to the original author(s) and the source, provide a link to the Creative Commons license, and indicate if changes were made.

\section{References}

Adelaar, A. (2009). Loanwords in Malagasy. In M. Haspelmath \& U. Tadmor (Eds.), Loanwords in the world's languages: A comparative handbook (pp. 717-746). Amsterdam: De Gruyter Mouton.

Adelaar, A. (2016). Austronesians in Madagascar: A critical assessment of the works of Paul Ottino and Philippe Beaujard. In G. Campbell (Ed.), Early exchange between Africa and the wider Indian Ocean world. Palgrave series in Indian Ocean world studies (pp. 77-112). London: Palgrave Macmillan.

Albuquerque, U. P., Júnior, W. S. F., Santoro, F. R., Torres-Avilez, W. M., \& Júnior, J. R. S. (2015). Niche construction theory and ethnobiology. In U. P. Albuquerque, P. M. De Medeiros, \& A. Casas (Eds.), Evolutionary ethnobiology (pp. 73-87). Cham: Springer International Publishing.

Alexiades, M. N. (1999). Ethnobotany of the Ese Eja: Plants, health, and change in an Amazonian society. Ph.D. thesis, City University of New York. Retrieved February 1, 2018, from https://www. kent.ac.uk/sac/staff-profiles/profiles/staff_pdfs/alexiades_miguel/thesis.pdf

Amadiume, I. (2003). Culture summary: Igbo. Connecticut: HRAF. http://ehrafworldcultures.yale.edu/ document?id=ff26-000.

Asiedu, R., Wanyera, N. M., Ng, S. Y. C., \& Ng, N. Q. (1997). Yams. In D. Fuccillo, L. Sears, \& P. Stapleton (Eds.), Biodiversity in trust conservation and use of plant genetic resources in CGIAR centres (pp. 57-66). New York: Cambridge University Press. Retrieved September 20, 2017, from https://books.google.de/books?id=jLOiSPWy518C\&pg=PA64\&dq=dioscorea+cayenensis+labou 


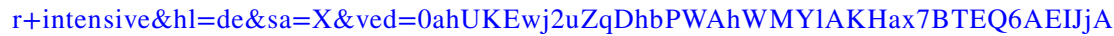
$\mathrm{A \#} \mathrm{v}=$ onepage $\& \mathrm{q}=$ dioscoreacayenensislabourintensive $\& \mathrm{f}=$ false.

Beaujard, P. (2011). The first migrants to Madagascar and their introduction of plants: Linguistic and ethnological evidence. Azania: Archaeological Research in Africa, 46(2), 169-189. https://doi. org/10.1080/0067270X.2011.580142.

Blakney, C. P. (1963). On 'banana' and 'iron': Linguistic footprints in African history. Hartford Studies in Linguistics, 13, 1-124.

Blench, R. (1996). The ethnographic evidence for long-distance contacts between Oceania and East Africa. In R. Blench \& J. Reade (Eds.), The Indian Ocean in antiquity (pp. 417-438). London: Kegan Paul.

Blench, R. (2006). Archaeology, language, and the African past. New York: Rowman Altamira.

Blench, R. (2007). Ancient connections between insular SE Asia and West Africa in the light of ethnobotanical and other evidence (unpublished)

Blench, R. (2009). Bananas and plantains in Africa: Re-interpreting the linguistic evidence. Ethnobotany Research and Applications, 7, 363-380. Retrieved April 9, 2017, from http://hl-128-171-57-22. library.manoa.hawaii.edu/handle/10125/12524.

Boardman, S. (1999). The agricultural foundation of the Aksumite Empire, Ethiopia: An interim report. In M. van der Veen (Ed.), The exploitation of plant resources in ancient Africa (pp. 137-148). New York: Plenum Press.

Boon, P. P. O. H., \& Corlett, R. T. (1989). Seed dispersal by the lesser short-nosed fruit bat (Cynopterus brachyotis, Pteropodidae Megachiroptera). Malayan Nature Journal, 42(October), 251-256.

Bostoen, Koen, Clist, B., Doumenge, C., Grollemund, R., Hombert, J.-M., Muluwa, J. K., et al. (2015). Middle to late Holocene paleoclimatic change and the early Bantu expansion in the rain forests of Western Central Africa. Current Anthropology, 56(3), 354-384. https://doi.org/10.1086/681436.

Bostoen, K., Grollemund, R., \& Muluwa, J. (2013). Climate-induced vegetation dynamics and the Bantu expansion: Evidence from Bantu names for pioneer trees (Elaeis guineensis, Canarium schweinfurthii, and Musanga cecropioides). Comptes Rendus Geoscience, 345(7-8), 336-349. https://doi. org/10.1016/J.CRTE.2013.03.005.

Bostoen, K., \& Muluwa, J. K. (2017). Were the first Bantu speakers south of the rainforest farmers? In M. Robbeets \& A. Savelyev (Eds.), Language dispersal beyond farming (pp. 235-258). Amsterdam/Philadelphia: John Benjamins Publishing Company. Retrieved April 19, 2017, from https:// books.google.de/books hl $=$ de $\& 1 \mathrm{r}=\& \mathrm{id}=5 \mathrm{Z} 5 \mathrm{BDwAAQBAJ} \& \mathrm{oi}=\mathrm{fnd} \& \mathrm{pg}=\mathrm{PA} 235 \& \mathrm{dq}=$ Bosto en+and+Koni+Muluwa+2017+\&ots=yEah4Zo-K0\&sig=ADTEV4pMM333mbAj62i7EYirZF0.

Bouquiaux, L., \& Thomas, J. M. C. (1980). Le peuplement oubanguien: Hypothèse de reconstruction des mouvements migratoires dans la région oubanguienne d'après les données linguistiques, ethnolinguistiques et de tradition orale. Société d'Etudes Linguistiques et Anthropologiques de France, 9, $807-824$.

Boyeldieu, P. (2009). Entre lac Albert et lac Tchad : L'expansion sara-bongo-baguirmienne. In H. Tourneux \& N. Woïn (Eds.), Migration et mobilité dans le bassin du lac Tchad: Actes du XIII colloque international Méga-Tchad, Maroua (pp. 239-252). Marseille: IRD Éditions.

Boyeldieu, P. (2010). Evaluating the genetic unity of Central Sudanic: Lexical and morphological evidence. Paper presented at the International workshop "Genealogical language classification in Africa beyond Greenberg”, Humboldt University Berlin, 21-22 February 2010. Berlin. Retrieved February 1, 2018, from https://www.iaaw.hu-berlin.de/de/afrika/linguistik-und-sprachen/veranstalt ungen/greenberg-workshop/evaluating-the-genetic-unity-of-central-sudanic-lexical-and-morph ological-evidence-1.

Boyeldieu, P. (2016). Expressing similarity in Yulu and some other SBB languages (Central Africa). In Y. Treis \& M. Vanhove (Eds.), Expressions of similarity from an Africanist and typological perspective (pp. 239-258). Amsterdam: John Benjamins Publishing Company.

Boyeldieu, P., \& Nougayrol, P. (2008). Les langues soudaniques centrales : Essai d'evaluation. Sprache und Geschichte in Afrika, 19, 9-29. Retrieved September 28, 2017, from https://halshs.archivesouvertes.fr/halshs-00348133.

Brandt, S. (1996). A model for the origins and evolution of enset food production. In T. Abate, C. Hiebsch, S. A. Brandt, \& S. Gebremariam (Eds.), Ensete-based sustainable agriculture in Ethiopia (pp. 36-46). Addis Ababa: IAR. Retrieved September 29, 2017, from https://scholar.google.de/schol ar?hl=de\&as_sdt $=0 \% 2$ C $5 \& \mathrm{q}=1996+$ brand+ethiopia + A+model+for+the+origins + and+evolu tion+of+enset+food+production. $+\& b \operatorname{tnG}=$. 
Bremond, L., Bodin, S. C., Bentaleb, I., Favier, C., \& Canal, S. (2017). Past tree cover of the Congo Basin recovered by phytoliths and $\delta 13 \mathrm{C}$ along soil profiles. Quaternary International, 434, 91-101. https ://doi.org/10.1016/J.QUAINT.2015.11.150.

Buerkert, A., De Langhe, E., \& Al Khanjari, S. (2009). Ecology and morphological traits of an ancient Musa acuminata cultivar from a mountain oasis of Oman. Genetic Resources and Crop Evolution, 56(5), 609-614. https://doi.org/10.1007/s10722-009-9442-2.

Bulmer, S. (1975). Settlement and economy in prehistoric Papua New Guinea: A review of the archeological evidence. Journal de la Société des océanistes, 31(46), 7-75. https://doi.org/10.3406/ jso.1975.2688.

Burkill, I. H. (1938). The contact of the Portuguese with African food-plants which gave words such as 'yam' to European languages. Proceedings of the Linnean Society of London, 150(2), 84-95. https ://doi.org/10.1111/j.1095-8312.1938.tb00154.x.

Burkill, I. H. (1939). Notes on the genus Dioscorea in the Belgian Congo. Bulletin du Jardin botanique de l'État a Bruxelles, 15(4), 345-392. Retrieved September 19, 2017, from http://www.jstor.org/ stable/pdf/3666821.pdf?refreqid=excelsior\%3A84f5e271ca58d993ac8caee1a85fb2c8.

Burkill, I. H. (1960). The organography and the evolution of Dioscoreaceae, the family of the yams. The Botanical Journal of the Linnean Society, 56(367), 319-412. https://doi. org/10.1111/j.1095-8339.1960.tb02508.x.

Castillo, C., \& Fuller, D. Q. (2010). Still too fragmentary and dependent upon chance? Advances in the study of early Southeast Asian archaeobotany. In B. Bellina, E. A. Bacus, T. O. Pryce, \& W. J. Christie (Eds.), Fifty years of archaeology in Southeast Asia: Essays in honour of Ian Glover (pp. 91-111). Bangkok: River Books.

Castillo, C., \& Fuller, D. Q. (2015). Bananas: The spread of a tropical forest fruit as an agricultural staple. In J. Lee-Thorp \& M. A. Katzenberg (Eds.), The Oxford handbook of the archaeology of diet (pp. 1-26). Oxford: Oxford University Press.

Chaïr, H., Traore, R. E., Duval, M. F., Rivallan, R., Mukherjee, A., Aboagye, L. M., et al. (2016). Genetic diversification and dispersal of Taro (Colocasia esculenta (L.) Schott). PLoS ONE, 11(6), e0157712. https://doi.org/10.1371/journal.pone.0157712.

Cheesman, E. E. (1947). Classification of the bananas: The genus Musa L. Kew Bulletin, 2(2), $106-117$. Retrieved April 19, 2017, from http://www.jstor.org/stable/4109207?casa_token=VwvjQ1DVwQ MAAAAA:fDY_y13ey81-wjwX-OoN0YxNe2iwhltktcPqYKQND7wauuTjHM0zJfun_N8dbg 5OG-zR8YqrkFjp_ZYOcoU70w411CJ5szwBs1NuQsm3FLX9wOXvzA.

Cloarec-Heiss, F. (1995). Emprunts ou substrat? Analyse des convergences entre le groupe banda et les langues du Soudan Central. In R. Nicolaï \& F. Rottland (Eds.), Proceedings of the Fifth Nilo-Saharan Linguistics Colloquium (pp. 321-355). Köln: Rudiger Köppe. Retrived September 28, 2017, from https://scholar.google.de/scholar?hl=en\&as_sdt=0\%2C5\&q=CloarecHeiss \%2C+France.+1995.+Emprunts+ou+substrat\%3F+Analyse+des+convergences+entre + le+groupe+banda+et+les+langues+du+Soudan+Central.+In+Nicolaï+and+Rottland+\%28eds $\% 29 \% 2 \mathrm{C}+321-355 . \& \mathrm{btnG}=$.

Cloarec-Heiss, F. (1998). Entre oubanguien et soudan central : Les langues banda. In I. Maddieson \& T. J. Hinnebusch (Eds.), Language history and linguistic description in Africa (pp. 1-16). Trenton and Asmara: Africa World Press. Retrived September 28, 2017, from https://scholar.googl e.de/scholar?hl=en\&as_sdt=0\%2C5\&q=Cloarec-Heiss\%2C+France.+1998.+Entre+oubanguien +et+soudan+central $\% 3 \mathrm{~A}+$ les+langues+banda.+In+Maddieson+and+Hinnebusch+\%28eds $\% 29 \% 2 \mathrm{C}+1-16 . \& \mathrm{btnG}=$.

Cornelissen, E. (2002). Human responses to changing environments in Central Africa between 40,000 and 12,000 B.P. Journal of World Prehistory, 16(3), 197-235. https://doi.org/10.1023/A:10209 49501304.

Craufurd, P. Q., Summerfield, R. J., Asiedu, R., \& Vara Prasad, P. V. (2001). Dormancy in yams. Experimental Agriculture, 37, 147-181. Retrived September 18, 2017, from http://www-personal.ksu. edu/ vara/craufurd-pq-ea01.pdf.

Crowther, A., Lucas, L., Helm, R., Horton, M., Shipton, C., Wright, H. T., et al. (2016). Ancient crops provide first archaeological signature of the westward Austronesian expansion. Proceedings of the National Academy of Sciences of the United States of America, 113(24), 6635-6640. https://doi. org/10.1073/pnas.1522714113.

D’Andrea, A. C., Kahlheber, S., Logan, A. L., \& Watson, D. J. (2007). Early domesticated cowpea (Vigna unguiculata) from Central Ghana. Antiquity, 81(313), 686-698. https://doi.org/10.1017/S0003 $598 X 00095661$. 
D’Hont, A., Denoeud, F., Aury, J.-M., Baurens, F.-C., Carreel, F., Garsmeur, O., et al. (2012). The banana (Musa acuminata) genome and the evolution of monocotyledonous plants. Nature, 488(7410), 213-217. https://doi.org/10.1038/nature11241.

Davies, M. (2014). Archaeology in South Sudan past and present: Gordon's fort at Laboré and other sites of interest. Sudan \& Nubia, 18, 165-176.

De Langhe, E. (2007). The establishment of traditional plantain cultivation in the African rain forest: A working hypothesis. In T. P. Denham, J. Iriarte, \& L. Vrydaghs (Eds.), Archaeological and ethnoarchaeological perspectives (pp. 361-370.). London NewYork: Routledge. Retrieved September 13, 2017, from https://books.google.de/books?hl=en\&lr=\&id=_GCTDAAAQBA $\mathrm{J} \&$ oi $=$ fnd $\& \mathrm{pg}=\mathrm{PA} 361 \& \mathrm{dq}=\mathrm{de}+$ langhe $+2007+$ banana\&ots $=$ SCZfvqwUJ7\&sig $=8 \mathrm{fnWdFZZOC}$ yXKvINbhS8XQxKMK4.

De Langhe, E. (2009). Relevance of banana seeds in archaeology. Ethnobotany Research and Applications, 7, 271-281.

De Langhe, E., \& De Maret, P. (1999). Tracking the banana: Its significance in early agriculture. In C. Gosden \& H. Jon (Eds.), The prehistory of food (pp. 377-396). London New York: Routledge. Retrieved April 9, 2017, from http://www.biw.kuleuven.be/DTP/TRO/PublicationsTRP L-pdf/1999/1999-VIII/ThePrehistoryOfFood_1999_p377-396.pdf.

De Langhe, E., Swennen, R., \& Vuylsteke, R. (1995). Plantain in the early Bantu world. Azania, 29-30, 47-60.

Denbow, J. R., \& Wilmsen, E. N. (1986). Advent and course of pastoralism in the Kalahari. Science, 234(4783), 1509-1515.

Denham, T. P. (2011). Early agriculture and plant domestication in New Guinea and Island Southeast Asia. Current Anthropology, 52(S4), S379-S395. https://doi.org/10.1086/658682.

Denham, T. P., Golson, J., \& Hughes, P. J. (2004). Reading early agriculture at Kuk Swamp, Wahgi Valley, Papua New Guinea: The archaeological features (Phases 1-3). Proceedings of the Prehistoric Society, 70, 259-297. https://doi.org/10.1017/S0079497X00001195.

Denham, T. P., Haberle, S. G., Lentfer, C. J., Fullagar, R., Field, J., Therin, M., Porch, N., \& Winsborough, B. (2003). Origins of agriculture at Kuk Swamp in the highlands of New Guinea. Science, 301(5630). Retrieved April 10, 2017, from http://science.sciencemag.org/content/301/5630/189. full.

de Schlippe, P. (1956). Shifting cultivation in Africa: The Zande system of agriculture. London: Routledge \& Paul. Retrieved September 26, 2017, from http://ehrafworldcultures.yale.edu/ehrafe/citat ion.do?method=citation \&forward $=$ searchFullContext \&col=collection $(\% 27 / \mathrm{eHRAF} /$ ethnography/ Africa/FO07\%27)\&docId=fo07-060\&tocOffsetId=tocPubInfoP.

Diby, L. N., Hgaza, V. K., Tie, T. B., \& Assa, A. (2009). Productivity of yams (Dioscorea spp.) as affected by soil fertility. Journal of Animal \& Plant Sciences, 5(2), 494-506. Retrieved September 14, 2017, from http://www.m.elewa.org/JAPS/2009/5.2/5.pdf.

Divale, W. T., \& Harris, M. (1976). Population, warfare, and the male supremacist complex. American Anthropologist, 78(3), 521-538. https://doi.org/10.1525/aa.1976.78.3.02a00020.

Ehret, C. (1979). On the antiquity of agriculture in Ethiopia. Journal of African History, 20(20), 161-177.

Ehret, C. (2016). Bananas in Africa: What linguistic evidence requires. Paper presented at 23rd Biennial Meeting of the Society of Africanist Archaeologists, Toulouse.

Eichhorn, B., \& Neumann, K. (2015). The enigma of Iron Age plant subsistence in the inner Congo Basin. In A. Florenzan \& R. Fornaciari (Eds.), Proceedings of the IWAA8. 8th International Workshop of African Archaeobotany (Vol. 146, pp. 73-75), Modena and Reggio Emilia.

Fujimoto, T. (2009). Taro (Colocasia esculenta [L.] Schott) cultivation in vertical wet-dry environments: Farmers' techniques and cultivar diversity in Southwestern Ethiopia. Economic Botany, 63(2), $152-166$.

Fullagar, R., Field, J., Denham, T. P., \& Lentfer, C. J. (2006). Early and mid Holocene tool-use and processing of taro (Colocasia esculenta), yam (Dioscorea sp.) and other plants at Kuk Swamp in the highlands of Papua New Guinea. Journal of Archaeological Science, 33(5), 595-614. https://doi. org/10.1016/j.jas.2005.07.020.

Fuller, D. Q. (2003). African crops in prehistoric South Asia: A critical review. In K. Neumann, A. Butler, \& S. Kahlheber (Eds.), Food, fuel and fields: Progress in African archaeobotany (pp. 239271). Köln: Heinrich-Barth-Institut.

Fuller, D. Q., Boivin, N., Hoogervorst, T., \& Allaby, R. G. (2011). Across the Indian Ocean: The prehistoric movement of plants and animals. Antiquity, 85(328), 544-558. https://doi.org/10.1017/S0003 $598 \times 00067934$. 
Fuller, D. Q., Korisettar, R., Venkatasubbaiah, P. C., \& Jones, M. K. (2004). Early plant domestications in southern India: Some preliminary archaeobotanical results. Vegetation History and Archaeobotany, 13(2), 115-129. https://doi.org/10.1007/s00334-004-0036-9.

Fuller, D. Q., \& Madella, M. (2009). Banana cultivation in South Asia and East Asia: A review of the evidence from archaeology and linguistics. Ethnobotany Research and Applications, 7, 333-351. https://doi.org/10.17348/era.7.0.333-351.

Gautier, A. (1984). Archaeozoology of the Bir Kiseiba region, eastern Sahara. In F. Wendorf, R. Schild, \& A. E. Close (Eds.), Cattle-keepers of the Eastern Sahara: The Neolithic of Bir Kiseiba (pp. 49-57). Dallas: Department of Anthropology, Southern Methodist University.

Giblin, J. D., \& Fuller, D. Q. (2011). First and second millennium AD agriculture in Rwanda: Archaeobotanical finds and radiocarbon dates from seven sites. Vegetation History and Archaeobotany, 20(4), 253-265. https://doi.org/10.1007/s00334-011-0288-0.

Gifford-Gonzalez, D. (2000). Animal disease challenges to the emergence of pastoralism in sub-Saharan Africa. African Archaeological Review, 17(3), 95-139. https://doi.org/10.1023/A:1006601020217.

Gifford-Gonzalez, D. (2017). 'Animal disease challenges' fifteen years later: The hypothesis in light of new data. Quaternary International, 436, 283-293. https://doi.org/10.1016/j.quain t.2015.10.054.

Gopal, L. (1964). Sugar-making in ancient India. Journal of the Economic and Social History of the Orient, 7(1), 57-72. https://doi.org/10.1163/156852064X00030.

Goude, G., Salazar-García, D. C., Power, R. C., Terrom, J., Rivollat, M., Deguilloux, M.-F., et al. (2019). A multidisciplinary approach to Neolithic life reconstruction. Journal of Archaeological Method and Theory, 26, 537-560. https://doi.org/10.1007/s10816-018-9379-x.

Greenberg, J. H. (1963). The languages of Africa. Bloomington: Indiana University Press.

Greenberg, J. H. (1972). Linguistic evidence regarding Bantu origins. The Journal of African History, 13(02), 189. https://doi.org/10.1017/S0021853700011427.

Grimaldi, I. M. (2013). Food for thought: Genetic, historical and ethnobotanical studies of Taro (Colocasia esculenta (L.) Schott) in Africa. Ph.D. thesis, Oxford University.

Grimaldi, I. M. (2016). Taro across the oceans: Journeys of one of our oldest crops. In U. Thanheiser (Ed.), Advances in archaeobotany (Vol. 3, pp. 67-81). Eelde: Barkhuis.

Grimaldi, I. M., Muthukumaran, S., Tozzi, G., Nastasi, A., Boivin, N., Matthews, P. J., et al. (2018). Literary evidence for taro in the ancient Mediterranean: A chronology of names and uses in a multilingual world. PLoS ONE, 13(6), e0198333. https://doi.org/10.1371/journal.pone.01983 33.

Grivet, L., Daniels, C., Glaszmann, J. C., \& D’Hont, A. (2004). A review of recent molecular genetics evidence for sugarcane evolution and domestication. Ethnobotany Research and Applications, 2, 9-17.

Grollemund, R., Branford, S., Bostoen, K., Meade, A., Venditti, C., \& Pagel, M. (2015). Bantu expansion shows that habitat alters the route and pace of human dispersals. Proceedings of the National Academy of Sciences of the United States of America, 112(43), 13296-13301.

Güldemann, T. (2017). A shared pronominal canon in the Macro-Sudan belt: Typological, areal and genealogical perspectives. In R. Kramer \& R. Kießling (Eds.), Mechthildian approaches to Afrikanistik: Advances in language based research in Africa (pp. 101-146). Köln: Rüdiger Köppe.

Güldemann, T. (2018a). Historical linguistics and genealogical classification. In T. Güldemann (Ed.), The languages and linguistics of Africa. Berlin: Mouton de Gruyter.

Güldemann, T. (2018b). Areal linguistics beyond contact, and linguistic areas of Afrabia. In T. Güldemann (Ed.), The languages and linguistics of Africa. Berlin: Mouton de Gruyter.

Haberle, S. G. (1995). Identification of cultivated Pandanus and Colocasia in pollen records and the implications for the study of early agriculture in New Guinea. Vegetation History and Archaeobotany, 4(4), 195-210. https://doi.org/10.1007/BF00235751.

Hammer, R. L. (1998). Diagnosis: Dioscorea. Wildland Weeds, (12), 8-10. Retrieved September 19, 2017, from https://scholar.google.de/scholar?hl=en\&q=Hamme $\mathrm{r}+\mathrm{RL} \% 2 \mathrm{C}+1998 .+\mathrm{Di}$ a n os is $\% 3 \mathrm{~A}+\mathrm{Di}$ os c orea.+ Wild l and + Weeds $\% 2 \mathrm{C}+2 \% 281 \% 29 \% 3 \mathrm{~A} 8-10 . \& \mathrm{btnG}=\&$ as_sdt=1\%2C5\&as_sdtp=.

Hanna, P. R. (1964). Beyond the Americas. Chicago: Scott. Retrieved October 15, 2017, from https:// books.google.de/books?id=t0JMAQAAIAAJ\&q=banana+africa+overgrown+cleared\&dq=banan $\mathrm{a}+$ africa+overgrown+cleared $\& \mathrm{hl}=$ en $\& \mathrm{sa}=\mathrm{X} \& \mathrm{ved}=0 \mathrm{ahUKEwibtMG2nfPWAhXB2RoKHcY8C}$ LoQ6AEIWDAJ. 
Hannah, T. (2000). Early history. In J. Kingsman \& C. Gafner (Eds.), Sugar trading manual (pp. 1-14). Cambridge: Woodhead.

Heckmann, M. (2011). Soil erosion history and past human land use in the North Pare mountains: A geoarchaeological study of slope deposits in NE Tanzania. Ph.D. thesis, University of York.

Hildebrand, E. A. (2003). Enset, yams, and honey: Ethnoarchaeological approaches to the origins of horticulture in southwest Ethiopia. Ph.D. thesis, Washington University. Retrieved February 1, 2018, from https://elibrary.ru/item.asp?id=8844635.

Hildebrand, E. A. (2007). A tale of two tuber crops: How attributes of enset and yams may have shaped prehistoric human-plant interactions in Southwest Ethiopia. In T. P. Denham, J. Iriarte, \& Luc Vrydaghs (Eds.), Rethinking agriculture: Archaeological and ethnoarchaeological perspectives (pp. 273-298). New York: Left Coast Press. Retrieved September 19, 2017, from https://books.googl e.de/books hl =en\&lr=\&id=_GCTDAAAQBAJ\&oi=fnd\&pg=PA273\&dq=hildebrand+enset \&ots=SDQjypzZEb\&sig=y6qMNCzYoi1-of5QuEfp_kcXIjw\#v=onepage\&q=hildebrandenset $\& \mathrm{f}=$ false.

Hildebrand, E. A. (2009). The utility of ethnobiology in agricultural origins research. Current Anthropology, 50(5), 693-697. https://doi.org/10.1086/605569.

Hildebrand, E. A., Brandt, S. A., \& Lesur-Gebremariam, J. (2010). The Holocene archaeology of Southwest Ethiopia: New insights from the Kafa archaeological project. African Archaeological Review, 27(4), 255-289. https://doi.org/10.1007/s10437-010-9079-8.

Hillman, G. C. (1989). Late Palaeolithic plant foods from Wadi Kubbaniya in Upper Egypt: Dietary diversity, infant weaning, and seasonality in a riverine environment. In D. Harris (Ed.), Foraging and farming: The evolution of plant exploitation (pp. 205-233). London: Unwin Hyman.

Hodson, M. J., White, P. J., Mead, A., \& Broadley, M. R. (2005). Phylogenetic variation in the silicon composition of plants. Annals of Botany, 96(6), 1027-1046. https://doi.org/10.1093/aob/mci255.

Honegger, M. (2005). Kerma et les débuts du Néolithique africain. Genava, 53, 239-249.

Huang, H. (2012). Yu Jing (The book of taro). In M. Spriggs, D. Addison, \& P. J. Matthews (Eds.), Irrigated taro (Colocasia esculenta) in the Indo-Pacific: Biological, social and historical perspectives (pp. 45-51). Osaka: National Museum of Ethnology.

Ichikawa, M., \& Terashima, H. (1996). Cultural diversity in the use of plants by Mbuti hunter-gatherers in northeastern Zaire: An ethnobotanical approach. In S. Kent (Ed.), Cultural diversity among twentieth-century foragers (pp. 276-293). Cambridge: Cambridge University Press. Retrieved June 3, 2017, from https://books.google.it/books?hl=en\&lr=\&id=goNyYtJ77W0C\&oi=fnd\&pg=PA276 $\& d q=i c h i k a w a+$ cultural+diversity+in+the+use+of+plants + northeastern+zaire +mbuti \&ots=prbsFgcEFO\&sig=9HVYgtyiXc42uaFR0QtN6NE0AuY.

Inglett, G. E., \& Charalambous, G. (1979). Tropical food chemistry and nutrition. London New York: Academic Press. Retrieved September 25, 2017, from https://books.google.de/books?id=BblzmgkHFU $\mathrm{IC} \& \mathrm{pg}=\mathrm{PA} 250 \& \mathrm{dq}=$ dioscorea + alata + advantage + cayenensis $\& \mathrm{hl}=\mathrm{de} \& \mathrm{sa}=\mathrm{X} \& \mathrm{ved}=0 \mathrm{ahUKEwiv0}$ dabj8HWAhUGvRQKHeaQAoAQ6AEIQTAE\#v=onepage \&q=dioscoreaalataadvantagecayenen sis\& $\mathrm{f}=$ false.

Iriarte, J. (2007). New perspectives on plant domestication and the development of agriculture in the New World. In T. P. Denham, J. Iriarte, \& L. Vrydaghs (Eds.), Rethinking agriculture: Archaeological and ethnoarchaeological perspectives (pp. 167-188). Walnut Creek: Left Coast Press.

Ivancic, A., \& Lebot, V. (2000). The genetics and breeding of taro. Montpellier: CIRAD-CA. Retrieved September 14, 2017, from https://books.google.de/books?hl=en\&lr=\&id=8XCEM MefMC0C\&oi $=$ fnd \&pg $=$ PA $7 \& d q=$ The + Genetics + and +Breeding + of + Taro \&ots=_qbhjt XqGi\&sig=VDdoIexRCo712hfmqojOJ6bFwVU.

Johns, T., \& Kubo, I. (1988). A survey of traditional methods employed for the detoxification of plant foods. Journal of Ethnobiology, 8, 81-129. Retrieved October 13, 2017, from https://schol ar.google.de/scholar?hl=en\&as_sdt=0\%2C5\&q=A+SURVEY+OF+TRADITIONAL+METHO $\mathrm{DS}+\mathrm{EMPLOYED}+\mathrm{FOR}+\mathrm{THE}+\mathrm{DETOXIFICA}+\mathrm{nON}+\mathrm{OF}+\mathrm{PLANT}+\mathrm{FOOD} \& \mathrm{btnG}=$.

Johnston, H. H. (1904a). The Uganda protectorate: An attempt to give some description of the physical geography, botany, zoology, anthropology, languages and history of the territories under British protection in East Central Africa, between the Congo Free State and the Rift Vall (Vol. 2). London: Hutchinson \& Co. Retrieved October 12, 2017, from https://scholar.google.de/scholar?hl=de\&as $\mathrm{sdt}=0 \% 2 \mathrm{C} 5 \& \mathrm{q}=\mathrm{The}+\mathrm{Ugand} \mathrm{a}+$ Protectorate $\% 3 \mathrm{~A}+\mathrm{Attempt}+\mathrm{to}+\mathrm{Give}+\mathrm{Some}+\mathrm{Descriptio}$ $\mathrm{n}+\mathrm{of}+$ the + Physical+Geography $\% 2 \mathrm{C}+$ Botany $\% 2 \mathrm{C}+$ Zoology $\% 2 \mathrm{C}+$ Anthropology $\% 2 \mathrm{C}+\mathrm{Langu}$ ages+and+History+of+the+Territories+under+British+Protection+in+East+. 
Johnston, H. H. (1904b). The Uganda protectorate; An attempt to give some description of the physical geography, botany, zoology, anthropology, languages and history of the territories under British protection in East Central Africa, between the Congo Free State and the Rift Vall (Vol. 1). London: Hutchinson \& Co. Retrieved September 16, 2017, from http://www.biodiversitylibrary.org/ item/60151.

Jones, A. M. (1964). Africa and Indonesia: The evidence of the xylophone and other musical factors. Leiden: Brill.

Jones, A. M. (1972). Elephantiasis and music. African Music Society Journal, 5(2), 46-49.

Kahlheber, S., Eggert, M. K. H., Seidensticker, D., \& Wotzka, H.-P. (2014a). Pearl millet and other plant remains from the early Iron Age site of Boso-Njafo (inner Congo Basin, Democratic Republic of the Congo). African Archaeological Review, 31(3), 479-512. https://doi.org/10.1007/s1043 7-014-9168-1.

Kahlheber, S., Höhn, A., \& Neumann, K. (2014b). Plant and land use in Southern Cameroon 400 BCE400 CE. In C. J. Stevens, S. Nixon, M. A. Murray, \& D. Q. Fuller (Eds.), The archaeology of African plant use (pp. 113-129). Walnut Creek: Left Coast Press.

Kahlheber, S., Neumann, K., \& Bostoen, K. (2009). Early plant cultivation in the Central African rain forest: First millennium BC pearl millet from South Cameroon. Journal of African Archaeology, 7(2), 253-272. https://doi.org/10.3213/1612-1651-10142.

Kajale, M. D. (1989). Mesolithic exploitation of wild plants in Sri Lanka: Archaeobotanical study at the cave site of Beli-Lena. In D. R. Harris \& G. C. Hillman (Eds.), Foraging and farming: The evolution of plant exploitation (pp. 269-281). London: Routledge.

Kanshie, T. K. (2002). Five thousand years of sustainability? A case study on Gedeo land use (Southern Ethiopia). Ph.D thesis, Treemail Publishers, Heelsum. Retrieved February 1, 2018, from https:// core.ac.uk/download/pdf/29297194.pdf.

Kellman, M., \& Tackaberry, R. (1997). Tropical environments. London New York: Routledge Physical Environment Series.

Kennedy, J. (2009). Bananas and people in the homeland of genus Musa: Not just pretty fruit. Ethnobotany Research and Applications, 7, 179-198. https://doi.org/10.17348/era.7.0.179-197.

Kitanishi, K. (2003). Cultivation by the Baka hunter-gatherers in the tropical rain forest of Central Africa. African Study Monographs, 28, 143-157. Retrieved April 9, 2017, from http://repository.kulib .kyoto-u.ac.jp/dspace/bitstream/2433/68423/1/ASM_S_28_143.pdf.

Kitavi, M., Downing, T., Lorenzen, J., Karamura, D., Onyango, M., Nyine, M., et al. (2016). The triploid East African Highland Banana (EAHB) genepool is genetically uniform arising from a single ancestral clone that underwent population expansion by vegetative propagation. Theoretical and Applied Genetics, 129(3), 547-561. https://doi.org/10.1007/s00122-015-2647-1.

Klapwijk, M., \& Huffman, T. N. (1996). Excavations at silver leaves: A final report. The South African Archaeological Bulletin, 51, 84-93. Retrieved September 18, 2017, from https ://scholar.google.de/scholar?hl=en \&q=Klapwijk +M\%2C+Huffm an $+\mathrm{T}+\% 28199$ $6 \% 29+$ Excavation + at + silver+leaves $\% 3 \mathrm{~A}+\mathrm{a}+$ final +report. + South + Afric an + Archa eol+Bull+51\%3A84-93\&btnG=\&as_sdt=1\%2C5\&as_sdtp=.

Kreike, C. M., Van Eck, H. J., \& Lebot, V. (2004). Genetic diversity of taro, Colocasia esculenta (L.) Schott, in Southeast Asia and the Pacific. Theoretical and Applied Genetics, 109(4), 761-768. https ://doi.org/10.1007/s00122-004-1691-z.

Lebot, V. (1999). Biomolecular evidence for plant domestication in Sahul. Genetic Resources and Crop Evolution, 46(6), 619-628. https://doi.org/10.1023/A:1008748504038.

Lebot, V. (2009). Tropical root and tuber crops: Cassava, sweet potato, yams and aroids. Crop production science in horticulture (Vol. 17). Wallingford: CIRAD. https://doi.org/10.1017/S001447970 9007832

Lejju, B. J., Robertshaw, P., \& Taylor, D. (2006). Africa's earliest bananas? Journal of Archaeological Science, 33(1), 102-113. https://doi.org/10.1016/j.jas.2005.06.015.

Lejju, B. J., Taylor, D., \& Robertshaw, P. (2005). Late-Holocene environmental variability at Munsa archaeological site, Uganda: A multicore, multiproxy approach. The Holocene, 15(7), 1044-1061. https://doi.org/10.1191/0959683605hl877ra.

Lentfer, C. J. (2009). Going bananas in Papua New Guinea: A preliminary study of starch granule morphotypes in Musaceae fruit. Ethnobotany Research and Applications, 7, 217-238. Retrieved April 19, 2018, from https://scholarspace.manoa.hawaii.edu/handle/10125/12516. 
Lentfer, C. J., \& Denham, T. P. (2017). The archaeobotany of Kuk. In J. Golson, T. Denham, P. Hughes, P. Swadling, \& J. Muke (Eds.), Ten thousand years of cultivation at Kuk Swamp in the highlands of Papua New Guinea (pp. 163-184). Canberra: ANU Press.

Livingstone Smith, A., Cornelissen, E., de Francquen, C., Nikis, N., Mees, F., Tshibamba Mukendi, J., et al. (2017). Forests and rivers: The archaeology of the north eastern Congo. Quaternary International, 448, 95-116. https://doi.org/10.1016/j.quaint.2016.10.010.

Madella, M. (2003). Investigating agriculture and environment in South Asia: Present and future contributions from opal phytoliths. In S. Weber \& W. Belcher (Eds.), Indus ethnobiology: New perspectives from the field (pp. 199-249). Lanham: Lexington Books.

Maduelosi, N. J., \& Angaye, S. S. (2015). Characterization of African elemi (Canarium Schweinfurthii). International Journal of Advanced Research in Chemical Science, 2(11), 34-36. Retrieved July 14, 2017, from www.arcjournals.org.

Maggs, T. (1994). The south-east: The early Iron Age in the extreme south: Some patterns and problems. Azania, 29-30(1), 168-178. https://doi.org/10.1080/00672709409511669.

Maley, J. (2002). A catastrophic destruction of African forests about 2,500 years ago still exerts a major influence on present vegetation formations. IDS Bulletin, 33(1), 13-30. https://doi. org/10.1111/j.1759-5436.2002.tb00003.x.

Maley, J., Doumenge, C., Giresse, P., Mahé, G., Philippon, N., Hubau, W., et al. (2018). Late Holocene forest contraction and fragmentation in central Africa. Quaternary Research, 89(01), 43-59. https ://doi.org/10.1017/qua.2017.97.

Manning, K., Pelling, R., Higham, T., Schwenniger, J. L., \& Fuller, D. Q. (2011). 4500-year old domesticated pearl millet (Pennisetum glaucum) from the Tilemsi Valley, Mali: New insights into an alternative cereal domestication pathway. Journal of Archaeological Science, 38(2), 312-322. https:// doi.org/10.1016/j.jas.2010.09.007.

Marshall, F., \& Hildebrand, E. (2002). Cattle before crops: The beginnings of food production in Africa. Journal of World Prehistory, 16(2), 99-144. https://doi.org/10.1023/A:1019954903395.

Matthews, P. J. (1995). Aroids and the Austronesians. Tropics, 4(2), 105-126. https://doi.org/10.3759/ tropics.4.105.

Mbida, C., Doutrelepont, H., Vrydaghs, L., Swennen, R., Swennen, R., Beeckman, H., et al. (2005). The initial history of bananas in Africa. A reply to Jan Vansina, Azania, 2003. Azania, 40(1), 128-135. https://doi.org/10.1080/00672700509480419.

Mbida Mindzié, C., Doutrelepont, H., Vrydaghs, L., Swennen, R. L., Swennen Rudy, J., Beeckman, H., et al. (2001). First archaeological evidence of banana cultivation in central Africa during the third millennium before present. Vegetation History and Archaeobotany, 10, 1-6. https://doi. org/10.1007/PL00013367.

Mbida Mindzié, C., Van Neer, W., Doutrelepont, H., \& Vrydaghs, L. (2000). Evidence for banana cultivation and animal husbandry during the first millennium BC in the forest of Southern Cameroon. Journal of Archaeological Science, 27(2), 151-162. https://doi.org/10.1006/jasc.1999.0447.

McMartin, A. (1961). Sugarcane in Central and East Africa: Some observations on its history and present position. Proceedings of the South African Sugar Technologists' Association, 104-109. Retrieved April 10, 2017, from http://www.sasta.co.za/wp-content/uploads/Proceedings/1960s/1961_Mcmar tin_Sugarcane. In Central And.pdf.

Mignouna, H., Mank, R., Ellis, T., van den Bosch, N., Asiedu, R., Abang, M., et al. (2002). A genetic linkage map of water yam (Dioscorea alata L.) based on AFLP markers and QTL analysis for anthracnose resistance. Theoretical and Applied Genetics, 105(5), 726-735.

Moñino, Y. (1988). Lexique comparatif des langues oubanguiennes. Paris: Paul Geuthner.

Moñino, Y. (1995). Le Proto-Gbaya : Essai de linguistique comparative historique sur vingt-et-une langues d'Afrique centrale. Louvain-Paris: Peeters Publishers.

Moñino, Y. (2010). The position of Gbaya-Manza-Ngbaka group among the Niger-Congo languages. In "Genealogical Language Classification in Africa beyond Greenberg," Humboldt University Berlin, 21-22 February 2010.

Morin-Rivat, J., Fayolle, A., Favier, C., Bremond, L., Gourlet-Fleury, S., Bayol, N., et al. (2017). Presentday central African forest is a legacy of the 19th century human history. eLife, 6, 10-20. https://doi. org/10.7554/eLife.20343.

Morton, J. F. (1987). Fruits of warm climates. Miami: Creative Resource Systems. Retrieved September 10, 2017, from https://www.cabdirect.org/cabdirect/abstract/19876763104.

Murdock, G. P. (1959). Africa: Its peoples and their culture history. New York: McGraw Hill. 
Murdock, G. P. (1960). Staple subsistence crops of Africa. Geographical Review, 50, 523-540. Retrieved July 8, 2017, from http://www.jstor.org/stable/212308.

Neumann, K., Bostoen, K., Höhn, A., Kahlheber, S., Ngomanda, A., \& Tchiengué, B. (2012). First farmers in the Central African rainforest: A view from Southern Cameroon. Quaternary International, 249, 53-62. https://doi.org/10.1016/j.quaint.2011.03.024.

Neumann, K., \& Hildebrand, E. (2009). Early bananas in Africa: The state of the art. Ethnobotany Research and Applications, 7, 353. https://doi.org/10.17348/era.7.0.353-362.

Ngo Ngwe, M. F. S., Omokolo, D. N., \& Joly, S. (2015). Evolution and phylogenetic diversity of Implication for conservation and agricultural practices. PLOS ONE, 10(12), 15-20. https://doi.org/10.1371/ journal.pone.0145364.

Ngomanda, A., Neumann, K., Schweizer, A., \& Maley, J. (2009). Seasonality change and the third millennium BP rainforest crisis in southern Cameroon (Central Africa). Quaternary Research, 71(3), 307-318. https://doi.org/10.1016/j.yqres.2008.12.002.

Onwueme, I. (1999). Taro cultivation in Asia. Bangkok: Food and agriculture organization of the United Nations Regional office for Asia and the Pacific.

Oslisly, R., Bentaleb, I., Favier, C., Fontugne, M., \& Gillet, J. F. (2013). West Central African peoples: Survey of radiocarbon dates over the past 5000 years. Radiocarbon, 55(3), 1377-1382. Retrieved September 17, 2017, from https://www.cambridge.org/core/journals/radiocarbon/article/div-class titlewest-central-african-peoples-survey-of-radiocarbon-dates-over-the-past-5000-yearsdiv/095DA 61BC7A725C218D6C083772EA208.

Panghal, V. P. S., \& Rana, M. K. (2017). Elephant foot yam. In M. K. Rana (Ed.), Vegetable crop science (pp. 73-78). Boca Raton: CRC Press.

Pawlowicz, C. M. (2011). Finding their place in the Swahili world: An archaeological exploration of southern Tanzania. Ph.D. thesis, University of Virginia.

Perera, N., Kourampas, N., Simpson, I. A., Deraniyagala, S. U., Bulbeck, D., Kamminga, J., et al. (2011). People of the ancient rainforest: Late Pleistocene foragers at the Batadomba-lena rockshelter, Sri Lanka. Journal of Human Evolution, 61(3), 254-269.

Perrier, X., De Langhe, E., Donohue, M., Lentfer, C. J., Vrydaghs, L., Bakry, F., et al. (2011). Multidisciplinary perspectives on banana (Musa spp.) domestication. Proceedings of the National Academy of Sciences of the United States of America, 108(28), 11311-11318.

Plucknett, D. (1976). Edible aroids. In N. W. Simmonds (Ed.), Evolution of crop plants (pp. 10-12). London: Longmans.

Pomerantz, S. (2017). The prehistory of Madagascar: Microbotanical and archaeological evidence from coastal and highland sites. Ph.D. thesis, Oxford University.

Potter, D., \& Doyle, J. J. (1992). Origins of the African yam bean (Sphenostylis stenocarpa, leguminosae): Evidence from morphology, isozymes, chloroplast DNA, and linguistics. Economic Botany, 46(3), 276-292. https://doi.org/10.1007/BF02866626.

Power, R. C., Salazar-García, D. C., Wittig, R. M., Freiberg, M., \& Henry, A. G. (2015). Dental calculus evidence of Taï Forest Chimpanzee plant consumption and life history transitions. Scientific Reports, 5, 15161. https://doi.org/10.1038/srep15161.

Price, N. S. (1995). The origin and development of banana and plantain cultivation. In S. Gowen (Ed.), Bananas and plantains (pp. 2-6). London: Chapman \& Hall.

Pryor, A. J. E., Steele, M., Jones, M. K., Svoboda, J., \& Beresford-Jones, D. G. (2013). Plant foods in the Upper Palaeolithic at Dolní Věstonice? Parenchyma redux. Antiquity, 87(338), 971-984. https:// doi.org/10.1017/S0003598X00049802.

Reed, R. (2015). Forest dwellers, forest protectors: Indigenous models for international development. Oxford: Routledge. Retrieved September 26, 2017, from https://books.google.de/books $? \mathrm{id}=\mathrm{zDKDC} g$ AAQB AJ $\& \mathrm{pg}=\mathrm{PT} 65 \& \mathrm{dq}=$ banan $\mathrm{a}+++$ fores $\mathrm{t}+$ shade ++ aband oned + recla im\&hl=de\&sa $=$ X\&ved=0ahUKEwj7v-q-k8PWAhXJOxQKHdN2DcUQ6AEIJjAA\#v=onepa ge $\& \mathrm{q}=$ banana $\& \mathrm{f}=$ false.

Robertshaw, P., \& Mawson, A. (1981). Excavations in Eastern Equatoria, Southern Sudan 1980. Archaeological Research in Africa, 16(1), 55-95. https://doi.org/10.1080/00672708109511286.

Robinson, H. A., Insoll, T., Kankpeyeng, B. W., Brown, K. A., \& Brown, T. A. (2017). Ritual complexity in a past community revealed by ancient DNA analysis of pre-colonial terracotta items from Northern Ghana. Journal of Archaeological Science, 79, 10-18. https://doi.org/10.1016/j. jas.2017.01.005.

Rossel, G. (1994). Musa and ensete in Africa: Taxonomy, nomenclature and uses. Archaeological Research in Africa, 29(1), 130-146. https://doi.org/10.1080/00672709409511666. 
Rossel, G. (1998). Taxonomic-linguistic study of plantain in Africa. Ph.D. thesis, Leiden University.

Russell, T., Silva, F., Steele, J., Avery, D. M., Wilson, M. L., Humphreys, A. J. B., et al. (2014). Modelling the spread of farming in the Bantu-speaking regions of Africa: An archaeology-based phylogeography. PLoS ONE, 9(1), e87854. https://doi.org/10.1371/journal.pone.0087854.

Sallares, R. (1991). The ecology of the ancient Greek world. London: Cornell University Press. Retrieved September 19, 2017, from https://books.google.de/books?hl=de\&lr=\&id=HQwnr8NgqQ YC\&oi=fnd\&pg $=$ PR7\&dq $=$ The + ecology + of + the + ancient + Greek + world $+: \&$ ots $=$ UjnQdnD5fX \&sig=JriuJjgf92_jQxcM4Thk7NsoS4I.

Sato, H. (2001). The potential of edible wild yams and yam-like plants as a staple food resource in the African tropical rain forest. African Study Monographs, Suppl.26(March), 123-134. Retrieved February 1, 2018, from http://repository.kulib.kyoto-u.ac.jp/dspace/handle/2433/68404.

Saxon, D. E. (1982). Linguistic evidence for the spread of the Ubangians. In C. Ehret \& M. Posnansky (Eds.), The archeological and linguistic reconstruction of African history (pp. 66-77). Berkeley: University of California Press.

Schoenbrun, D. L. (1993). Cattle herds and banana gardens: The historical geography of the western Great Lakes region, ca AD 800-1500. African Archaeological Review, 11(1), 39-72.

Schöffl, V., Varatorn, R., Blinnikov, O., \& Vidamaly, V. (2004). Intestinal obstruction due to phytobezoars of banana seeds: A case report. Asian Journal of Surgery, 27(4), 348-351.

Seidensticker, D. (2016). aDRAC. Archives des datations radiocarbone d'Afrique central (Vol. Version 0). Simmonds, N. W. (1962). The evolution of the bananas. London: Longmans.

Simmonds, N. W. (1976). Sugarcanes: Saccharum (Gramineae-Andropogoneae). In N. W. Simmonds (Ed.), Evolution of crop plants (pp. 104-108). London: Longman Group Ltd. Retrieved September 14, 2017, from http://agris.fao.org/agris-search/search.do?recordID=US201303063129.

Slesak, G., Mounlaphome, K., Inthalad, S., Phoutsavath, O., Mayxay, M., \& Newton, P. N. (2011). Bowel obstruction from wild bananas: A neglected health problem in Laos. Tropical Doctor, 41(2), 85-90. https://doi.org/10.1258/td.2011.100293.

Smole, W. J. (1976). The Yanoama Indians: A cultural geography. Austin: University of Texas Press. Retrieved October 15, 2017, from https://books.google.de/books?hl=de\&lr=\&id=dsfkDQAAQB AJ\&oi=fnd\&pg =PA99\&dq =+Yanoama+Indians: + A+Cultural+Geography\&ots=0mk8dxwIug $\&$ sig $=$ UCRparhkXC4ggOMyndspDxVhXac\#v=onepage \&q=YanoamaIndians\%3AACultura $1 \mathrm{Geography} \& \mathrm{f}=$ false.

Szolnoki, T. W. (1985). Food and fruit trees of the Gambia. Hamburg: Stiftung Walderhaltung in Afrika. Retrieved September 10, 2017, from https://www.cabdirect.org/cabdirect/abstract/19860610648.

Täckholm, V., Täckholm, G., \& Drar, M. (1941). Pteridophyta, Gymnospermae and Angio-spermae, part Monocotyledones Typhaceae-Gramineae. Flora of Egypt (Vol. 1). Cairo: Fouad I University.

Terashima, H. (2003). A comparative ethnobotany of the Mbuti and Efe hunter-gatherers in the Ituri forest, Democratic Republic of Congo. African Study Monographs, 24(2), 1-168. Retrieved September 10, 2017, from http://jambo.africa.kyoto-u.ac.jp/kiroku/asm_normal/abstracts/pdf/24-12/ichikawa_terashima2003.pdf.

Thomas, A. S. (1940). Uganda banana varieties and their uses. In J. D. Tothill (Ed.), Agriculture in Uganda (1st ed., pp. 116-120). Oxford: Oxford University Press.

Turnbull, C. M. (1965). The Mbuti pygmies: An ethnographic survey. Anthropological Papers of the American Museum of Natural History New York, 50(3), 262.

van der Veen, M. (2011). Consumption, trade and innovation: Exploring the botanical remains from the Roman and Islamic ports at Quseir al-Qadim. Frankfurt-am-Main: Africa Magna Verlag.

van der Veen, M., \& Morales, J. (2011). Summer crops-from trade to innovation. In M. van der Veen (Ed.), Consumption, trade and innovation: Exploring the botanical remains from the Roman and Islamic ports at Quseir al-Qadim, Egypt (pp. 75-119). Frankfurt: Africa Magna Verlag.

van der Veen, M., \& Morales, J. (2017). Food globalisation and the Red Sea: New evidence from the ancient ports at Quseir al-Qadim, Egypt. In D. A. Agius, E. Khalil, E. Scerri, A. Agius, \& W. D. A. (Eds.), Human interaction with the environment in the Red Sea: Selected papers of Red Sea Project VI (pp. 254-289). Leiden: Brill.

Van Neer, W. (2000). Domestic animals from archaeological sites in Central and West-Central Africa. In R.M. Blench \& K.C. MacDonald (Eds.), The origins and development of African livestock: Archaeology, genetics, linguistics and ethnography (pp. 163-190). London: UCL Press. Retrieved April 26, 2017, from https://lirias.kuleuven.be/1704942?limo=0.

Vansina, J. (1984). Western Bantu expansion. The Journal of African History, 25(2), 129-145.

Vansina, J. (1990). Paths in the rainforests: Toward a history of political tradition in Equatorial Africa. African Studies Review (Vol. 36). London: James Currey. 
Vansina, J. (2003). Bananas in Cameroun c. 500 BCE? Not proven. Azania, 38(1), 174-176.

Vilakazi, A. (1962). Zulu transformations: A study of the dynamics of social change. Pietermaritzburg: University of Natal Press.

Villareal, R. L. (1970). The vegetable industry's answer to the protein gap among low salaried earners. Sugar News Manilla, 46, 482-488.

Walsh, M. (2009). The use of wild and cultivated plants as famine foods on Pemba Island, Zanzibar. Études Océan Indien, 8(42-43), 217-241. https://doi.org/10.4000/oceanindien.793.

Walshaw, S. C. (2005). Swahili urbanization, trade, and food production: Botanical perspectives from Pemba Island, Tanzania, A.D. 600-1500. Ph.D. thesis, Washington University.

Warnier, J.-P. (1985). The history of the peopling of Western Cameroon and the genesis of its landscapes. Journal of African History, 25, 395-410.

Watson, A. M. (1983). Agricultural innovation in the early Islamic world. Cambridge: Cambridge University Press.

Wigboldus, J. S. (1994). The spread of crops into sub-equatorial Africa during the early Iron Age. Azania: Archaeological Research in Africa, 29-30(1), 121-129. https://doi.org/10.1080/0067270940 9511665.

Williamson, J. (1975). Useful plants of Malawi. Zomba: University of Malawi.

Winchell, F., Stevens, C. J., Murphy, C., Champion, L., \& Fuller, D. Q. (2017). Evidence for Sorghum domestication in fourth millennium BC Eastern Sudan: Spikelet morphology from ceramic impressions of the Butana group. Current Anthropology, 58(5), 673-683. https://doi.org/10.1086/693898.

Winkhart, B. (2015). The reconstruction of Mundu-Baka. Berlin: Humboldt Universität zu Berlin.

Woldekiros, H. S., \& D'Andrea, A. C. (2017). Early evidence for domestic chickens (Gallus gallus domesticus) in the Horn of Africa. International Journal of Osteoarchaeology, 27(3), 329-341. https://doi.org/10.1002/oa.2540.

Wotzka, H.-P. (1995). Studien zur Archäologie des Zentral-Afrikanischen Regenwaldes. Köln: Heinrich Barth Institut.

Yasuoka, H. (2013). Dense wild yam patches established by hunter-gatherer camps: Beyond the wild yam question, toward the historical ecology of rainforests. Human Ecology, 41(3), 465-475. Retrieved April 13, 2017, from http://link.springer.com/article/10.1007/s10745-013-9574-z.

Zerner, C. (2003). The viral forest in motion. In C. Wade (Ed.), In search of the rain forest (pp. 246-283). Durham: Duke University Press.

Publisher's Note Springer Nature remains neutral with regard to jurisdictional claims in published maps and institutional affiliations.

\section{Affiliations}

\section{Robert C. Power ${ }^{1,2,3,4} \mathbb{1}_{\mathbb{D}} \cdot$ Tom Güldemann $^{5,6} \cdot$ Alison Crowther $^{1,7} \mathbb{D}^{\mathbb{D}}$. Nicole Boivin ${ }^{1}$}

1 Department of Archaeology, Max Planck Institute for the Science of Human History, Jena, Germany

2 Institute for Pre-and Protohistoric Archaeology and Archaeology of the Roman Provinces, Ludwig-Maximilians-University Munich, Munich, Germany

3 Department of Human Evolution, Max Planck Institute for Evolutionary Anthropology, Leipzig, Germany

4 National Museum of Kenya, Nairobi, Kenya

5 Institute for Asian and African Studies, Humboldt Universität zu Berlin, Berlin, Germany

6 Department of Linguistics and Cultural Evolution, Max Planck Institute for the Science of Human History, Jena, Germany

7 School of Social Science, The University of Queensland, Brisbane, QLD, Australia 